\title{
Article
}

\section{The Efficacy of Functional Composts Manufactured Using Spent Coffee Ground, Rice Bran, Biochar, and Functional Microorganisms}

\author{
Aalfin-Emmanuel Santhanarajan, Yong-Hun Han and Sung-Cheol Koh * \\ Division of Civil, Environmental Engineering and Logistics System, Korea Maritime and Ocean University, \\ Busan 49112, Korea; eaalfi@gmail.com (A.-E.S.); sby81419@naver.com (Y.-H.H.) \\ * Correspondence: skoh@kmou.ac.kr; Tel.: +82-10-9900-7294
}

check for updates

Citation: Santhanarajan, A.-E.; Han, Y.-H.; Koh, S.-C. The Efficacy of Functional Composts Manufactured Using Spent Coffee Ground, Rice Bran, Biochar, and Functional Microorganisms. Appl. Sci. 2021, 11, 7703. https://doi.org/10.3390/ app11167703

Academic Editors: Rafael

López Núñez and Francisca Suárez Estrella

Received: 27 July 2021

Accepted: 19 August 2021

Published: 21 August 2021

Publisher's Note: MDPI stays neutral with regard to jurisdictional claims in published maps and institutional affiliations.

Copyright: (c) 2021 by the authors. Licensee MDPI, Basel, Switzerland. This article is an open access article distributed under the terms and conditions of the Creative Commons Attribution (CC BY) license (https:// creativecommons.org/licenses/by/ $4.0 /)$.

\begin{abstract}
Spent coffee grounds (SCGs), one of the world's most discarded wastes, may be an excellent resource as an organic fertilizer because of its richness in nutrients. The objective of this study was to develop a quality functional compost using SCGs, rice bran, biochar, SCG extract, and functional microbes (plant growth promoting and plant pathogen-suppression bacteria), and then to test their functional efficacy for a potential commercial application. Essentially, two types of representative composts ( $\mathrm{Tr} \_1$ and $\mathrm{Tr} \_5$ on the laboratory and pilot scale, respectively) were developed and passed all the official commercial quality standards. For pilot-scale composting, populations of Halotalea_uc, Corynebacterium nuruki, and Lactobacillus acidipiscis increased by augmentation of the composting microbes (MA-1) and the functional microbes (Bacillus cereus SB-3, Bacillus toyonensis SB-4, and Streptomyces sasae St-3). The higher total flavonoid content (11\% increase compared to control) of pepper leaves in PT-1 and the higher TEAC in PT-1 (36.2\%) and PT-2 (32.5\%) proved the efficacy of the functional composts bioaugmented with the functional microbes. The seedling growth of radish seeds treated with Streptomyces sasae St-3 as a biocontrol agent significantly increased despite the presence of the pathogen Fusarium oxysporum f. sp. lactucae. The total phenol content and TEAC in pepper plant leaves were significantly higher in $\operatorname{Tr} \_5$ than in the control (Tr_4), whereas there were no differences in Tr_4 and Tr_5 infested with the fungal pathogens, indicating that SB-3, SB-4, and St-3 cultures amended within the compost ( $\left.\operatorname{Tr} \_5\right)$ may facilitate the production of the antioxidants in the absence of the pathogens. However, a significant reduction in the antioxidants (total phenolic content and TEAC) was observed in the pepper plants whose roots were infected with the pathogens, indicating that the pathogens could neutralize functionalities of the functional microbes. It was concluded that the enhancement of functional microbes in the compost would aid in the biological control of pathogens in the soil environment. Further functional compost studies are necessary in terms of mechanisms of plant growth-promotion, mechanisms of pathogen suppression by the actinobacterial biocontrol agents, and interactions between the two mechanisms, as well as quality enhancement of the composts.
\end{abstract}

Keywords: spent coffee grounds (SCGs); rice bran; functional compost; antioxidant; plant-growth promoting bacteria; plant pathogen-suppression bacteria

\section{Introduction}

Compost is considered an environmentally-friendly soil amendment for growing crops because it better builds up more organic matter in the soil than chemical fertilizers [1] Composting is also an efficient way for organic waste reuse [2]. There is an urgent need to manage these wastes reasonably. In composting, microbes played a vital role in the degradation of organic matter [3]. The degradation products of cellulose can provide energy and carbon sources for the growth and reproduction of microbes [4]. Compost piles usually contain a mixture of carbon-rich and nitrogen-rich materials. Carbon-rich materials, such as woodchips, sawdust, and straw [5], are often shared between commercial composts and backyard composts. The choices for nitrogen-rich materials are based on 
accessibility. At the same time, animal manure is more economical and accessible for commercial composting. Such a difference in the selection of nitrogen-rich materials can cause different properties in the final compost products.

Coffee is the second most valuable commodity in the world after oil and its derivatives [6]. However, the processing of coffee cherries, and the milling of dried beans, roasting of green beans, and brewing of coffee contribute to environmental pollution by generating large amounts of bio-waste each year. Production of instant coffee and coffee brewing accounts for approximately 6 million tons of spent coffee grounds (SCGs) per year worldwide [7]. SCGs are usually mixed with common garbage [8,9], causing major environmental issues. Therefore, finding strategies to valorize the utilization of this organic residue is of much interest.

In today's society, the use of SCGs as a soil fertilizer (mineral addition) to promote plant growth is popular $[10,11]$. An alternative way to use SCGs is their processing into fertilizer without the costly and lengthy process of composting. In this way, organic matter unencumbered by pollution can be a valuable source of nutrients for organic farming, acting in support of the dissemination of the principles of sustainable agriculture. Horticultural plants grow poorly in soils amended with SCGs, likely due to phytotoxic effects [12].

Gomes et al. [13] reported that composting SCGs prior to use as fertilizer reduces toxicity to plants because the amount of phytotoxic compounds including heavy metals, ethylene, and ammonia present in SCGs is reduced. Composting is a common practice for recycling bio-waste and is regarded as a simple and efficient method to convert agricultural industrial wastes into stable, non-toxic, pathogen-free, and nutrient-rich products for soil conditioners and plant fertilizers [14]. The chemical composition of SCGs indicates several applications for this residue. For instance, the presence of nitrogen (about 1.2-2.3\%), phosphorus $(0.02-0.5 \%)$, and potassium $(0.35 \%)$ [15] suggests its utilization in agriculture as fertilizer or as a soil improver [16]. The contents of elements such as $\mathrm{K}, \mathrm{Mn}, \mathrm{Mg}$, and $\mathrm{Na}$ of lettuce significantly increased when coffee meal was properly mixed with municipal solid waste and composted (5\%) [17]. The high-temperature $\left(120-200^{\circ} \mathrm{C}\right)$ and high-pressure water treatment used in this method facilitates the extraction of water-soluble components from SCGs, including proteins, minerals, and organic acids [18]. However, there have been few studies on the application of the water-soluble extracts from SCGs for plant growth.

Rice bran was reported to have a good effect in optimizing the composting process, since it contains some essential material for microbial metabolism [19]. Chang and Chen [20] stated that rice bran was not a bulking agent in the food composting process. Rice bran has been reported to have a good effect to optimize the composting process, since it contains some essential materials for microbial metabolism $[19,21]$. Rice bran consists of many materials that are essential for microbial growth in organic solid waste composting processes. The use of fresh bran in upland vegetable crops sometimes creates germination inhibition, as well as growth suppression of the crop [22]. However, the influence of these materials on microbial metabolism is not yet known. Considering the above facts, the use of rice bran compost could be a useful way for eco-friendly and non-chemical weed control in organic farming systems of upland vegetables [22].

Biochar is a carbonaceous material obtained from pyrolysis of biomass residues in the absence of oxygen [23]. The physicochemical, chemical, and microbiological properties of a composting pile are favorable for the interaction with biochar, and, consequently, it is expected that a synergy would be established between the pool of organic matter, nutrients, and microbial biomass of the composting material and the physicochemical properties of biochar [24]. The addition of biochar during composting had several benefits: reducing the compost toxicity, the compost exhibiting higher moisture content and lower waste density, $\mathrm{N}$ retention during composting, and decreasing potentially pathogenic microorganisms [25]. Co-application of wheat straw (WS) and wheat straw biochar (WSB) with nutrients (MF) at $1 \%$ and $2 \%$ doses enhanced carbon and nitrogen contents in soil (i.e., their water soluble fractions such as DOC and DON) [26]. The synergistic effect of biochar and MF triggered the increase in the population density and activity of soil microorganisms. 
The typical pathogens found in the composting of municipal solids waste and sewage sludge can be viruses, bacteria, protozoa, or helminths. They are usually heat-sensitive. The heat generated during the composting process can eliminate them, leading to a pathogenfree end compost product, and can be defined as a disinfection or sanitization process [27]. In an in-vessel composting, Salmonella sp., Staphylococcus aureus, and Shigella sp. were removed, while the coliform counts were reduced by a 2-log scale after 40 days of composting [28]. Antibiotic resistance genes (ARGs) and mobile genetic elements (MGEs) were significantly removed by $22.8-99.7 \%$ during the thermophilic phase of composting facilitated by the compound microbial inoculants carrying Bacillus sp. and yeasts [29]. This composting was helpful to remove the pathogen from the final compost product.

Plant growth-promoting bacteria (PGPB) produce a wide variety of molecules, which improve plant growth and productivity. These PGPB increased the production of phytohormones or other molecules that protect plants from biotic and abiotic stress, increased mineral nutrition, modulating ethylene levels in plants and the production of volatile organic compounds [30]. Furthermore, PGPB act as a potential symbiont and degrades the xenobiotic compounds to protect the plants. Inoculation of PGPB along with a mixture of organic amendments and biochar could be an effective way to overcome the problem of heavy metal toxicity [31]. There have so far been few studies, to the best of our knowledge, regarding functional composts carrying PGPB and plant pathogen-inhibiting microbes.

In this study, we aimed to manufacture and commercialize eco-friendly and highquality functional composts using spent coffee grounds (and their extracts), biochar, rice bran, and functional microorganisms (plant growth-promoting bacteria and plant pathogeninhibiting actinomycetes). We also tried to evaluate functional efficacies of the composts in terms of commercial application quality, microbial community structures, plant-growth promotion, antioxidant production in crops, and plant pathogen inhibition.

\section{Materials and Methods}

2.1. Isolation and Selection of Plant Growth-Promoting Bacteria and Plant Pathogen Inhibiting Bacteria, and Their Growth Medium Preparation from Spent Coffee Grounds

The target strains for this study were Bacillus sp. (plant-growth-promotion function) and Actinomyces sp. (plant-pathogen-suppression function) that were isolated from forest soils at the Korea Maritime and Ocean University (Busan, Korea) to identify microorganisms and register a patent strain. The media for Bacillus sp. and Actinomyces sp. were trypticase soy agar (TSA, Difco) and International Streptomyces Project (ISP-4), respectively. To establish a proper medium for the functional microorganisms, three kinds of extractions of coffee beans were tried: (1) spent coffee grounds suspended in distilled water $(10 \%, w / w)$ and heat-treated $\left(121^{\circ} \mathrm{C}\right.$ for $\left.15 \mathrm{~min}\right) ;(2)$ spent coffee grounds suspended in distilled water $(10 \%, w / w)$ and extracted in a shaking incubator $(150 \mathrm{rpm})$ at $25^{\circ} \mathrm{C}$ for $1 \mathrm{~h}$; and (3) spent coffee grounds suspended in $80 \%$ ethanol $(10 \%, w / w)$ and extracted in a shaking incubator $(150 \mathrm{rpm})$ at $25{ }^{\circ} \mathrm{C}$ for $1 \mathrm{~h}$. Each medium was tested to grow the potential functional microbial isolates (SB-3, SB-4, and St-3). The growth status (density and contamination degree) was monitored by plating the cultures onto TSA (SB-3 and SB-4) and ISP (St-3) for 4 days. The best medium was chosen based on the highest growth status. The potential plant-growth-promoting bacteria were selected based on radish germination activity and its seedling growth activity after growing 20 radish seeds on sterilized filter paper soaked with $2 \mathrm{~mL}$ of the bacterial culture grown on the best SCG extraction medium for 3 days. The plant-pathogen-suppressing bacteria (Actinomyces sp.) were selected based on the growth inhibition effect of the bacteria (on ISP medium 4 agar plates) against known plant pathogens (Fusarium oxysporum f. sp. lycopersici KACC 40032, Fusarium oxysporum $\mathrm{f}$. sp. lactucae KACC 42795, Pythium ultimum KACC 40705, and Pythium sp. KACC 40581). The final selected isolates were identified using the $16 \mathrm{~S}$ rRNA gene analysis system at the Institute of Microbial Ecology and Resources, Mokwon University, Daejon, Korea. 


\subsection{Procedures for Composting Using Spent Coffee Grounds, Rice Bran, and Biochar, and Phytotoxicity Test for the Manufactured Composts}

The substrates used for composting were spent coffee grounds, rice bran, and biochar. The spent coffee grounds were collected from several local coffee shops in Yeongdo-gu, Busan, Korea, and dried in a shaded place to $40-50 \%$ moisture. Recipes for substrates and microbial inoculum used for the composting at the laboratory and pilot scales are shown in Table 1, and the composting process is shown in Figure 1. The percentages of spent coffee grounds, rice bran, and biochar in the mixtures were $81.5 \%(w / w), 15.8 \%$, and $2.5 \%$, respectively, on the laboratory scale, and $49.07 \%, 49.28 \%$, and $1.51 \%$, respectively, on the pilot scale. The aerobic composting was performed by augmenting the microbial agent (MA-1) [15] as a facilitator for the composting, and the augmentation ratios were $0.2 \%$ $(w / w)$ on the laboratory scale and $0.13 \%$ on the pilot scale. Each mixture was maintained under $50 \%$ moisture content at $50{ }^{\circ} \mathrm{C}$ for 7 days. Afterward, each compost was matured and stabilized by adding functional microbes (plant-growth-promoting bacteria and plantpathogen-inhibiting bacteria) grown on SCG extract $(10 \%, w / w)$ for 5 days. The moisture content $(50 \%)$ and temperature $\left(25-30{ }^{\circ} \mathrm{C}\right)$ were maintained for 7 days in the process.

Table 1. Recipes for substrate and microbial inoculum used for composting on the laboratory and pilot scales.

\begin{tabular}{|c|c|c|c|c|c|c|c|c|c|c|}
\hline \multirow[b]{2}{*}{ Code } & \multirow[b]{2}{*}{ Unit } & \multirow{2}{*}{$\begin{array}{l}\text { Location of } \\
\text { Substrates }\end{array}$} & \multicolumn{5}{|c|}{ Mixture of Substrates and Composting Microbes } & \multicolumn{2}{|c|}{$\begin{array}{c}\text { Inoculation of Functional } \\
\text { Microbes }\end{array}$} & \multirow{2}{*}{$\underset{\text { Cocation }}{\text { Composting }}$} \\
\hline & & & SPG & $\begin{array}{l}\text { Defatted } \\
\text { Rice Bran }\end{array}$ & Biochar & $\begin{array}{l}\text { Microbial } \\
\text { Inoculation } \\
\text { (MA-1) }\end{array}$ & $\begin{array}{l}\text { Total } \\
(\mathbf{k g})\end{array}$ & $\begin{array}{l}\text { Bacillus sp. } \\
\text { (SB-3 and SB-4) }\end{array}$ & $\begin{array}{l}\text { Streptomyces } \\
\text { sasae }(\mathrm{St}-3)\end{array}$ & \\
\hline \multirow{2}{*}{$\mathrm{NC}$} & $\%$ & \multirow{2}{*}{$\mathrm{Lab}$} & 81.5 & 16.0 & 2.5 & 0 & & 0 & 0 & \multirow[t]{2}{*}{ Lab } \\
\hline & $\mathrm{kg}$ & & 1.46 & 0.283 & 0.045 & 0 & 1.7 & 0 & 0 & \\
\hline \multirow{2}{*}{ Tr_1 } & $\%$ & \multirow{2}{*}{$\mathrm{Lab}$} & 81.5 & 16.0 & 2.5 & 0.2 & & 1 & 1 & \multirow[t]{2}{*}{ Lab } \\
\hline & $\mathrm{kg}$ & & 1.46 & 0.283 & 0.045 & 0.004 & 1.7 & $1.7 \mathrm{~mL}$ & $1.7 \mathrm{~mL}$ & \\
\hline \multirow{2}{*}{ Tr_2 } & $\%$ & \multirow{2}{*}{ Factory } & 47 & 50 & 3 & 0.2 & & 0 & 0 & \multirow[t]{2}{*}{ Lab } \\
\hline & $\mathrm{kg}$ & & 25.85 & 27.25 & 1.65 & 0.11 & 55 & 0 & 0 & \\
\hline \multirow{2}{*}{ Tr_3 } & $\%$ & \multirow{2}{*}{ Factory } & 47 & 50 & 3 & 0.2 & & 1 & 1 & \multirow[t]{2}{*}{$\mathrm{Lab}$} \\
\hline & $\mathrm{kg}$ & & 25.85 & 27.25 & 1.65 & 0.11 & 55 & $1.5 \mathrm{~L}$ & $1.5 \mathrm{~L}$ & \\
\hline \multirow{2}{*}{ Tr_4 } & $\%$ & \multirow{2}{*}{ Factory } & 47 & 50 & 3 & 0.2 & & 1 & 1 & \multirow[t]{2}{*}{ Factory } \\
\hline & $\mathrm{kg}$ & & 25.85 & 27.25 & 1.65 & 0.11 & 55 & $1.5 \mathrm{~L}$ & $1.5 \mathrm{~L}$ & \\
\hline \multirow{2}{*}{ Tr_5 } & $\%$ & \multirow{2}{*}{ Factory } & 47 & 50 & 3 & 0.2 & & 1 & 1 & \multirow{2}{*}{ Factory } \\
\hline & $\mathrm{kg}$ & & 25.85 & 27.25 & 1.65 & 0.11 & 55 & $1.5 \mathrm{~L}$ & $1.5 \mathrm{~L}$ & \\
\hline
\end{tabular}

Two types of composting vessels were used on the laboratory scale: round plastic bucket type (depth $\times$ height $=23 \times 29 \mathrm{~cm}$ ) and rectangular plastic trays (length $\times$ width $\times$ height $=70 \times 50 \times 20 \mathrm{~cm}$ ), all without a heat control system. The complete compost was dried to 40-50\% moisture and kept at cool room temperature until the subsequent experiments. Pilot composting was performed using a mixing and fermentation system for feedstuff (Model DDK-802F; $1120 \mathrm{~mm}(\mathrm{~W}) \times 2030 \mathrm{~mm}(\mathrm{H}) \times 2240 \mathrm{~mm}(\mathrm{~L})$; Daedongtech, Inc., Seoul, Korea; working volume 1300 L; automatic temperature control and mixing functions). Quality evaluation analysis of the manufactured composts was performed by AT Analysis Center Co., Ltd. (Incheon, Korea) according to the criteria required by the Office of Rural Development, Seoul, Korea. The phytotoxicity test for the composts was performed based upon the germination index of the test plants. Seed germination rate (GR) and root elongation (RE) were measured and calculated using the formula GI = GR $\times$ RE/100, where GI is the germination index, GR is the germination rate, and RE indicates root elongation [32]. 


\section{Mixing substrates and maceration}

\section{SCG, rice bran and biochar}

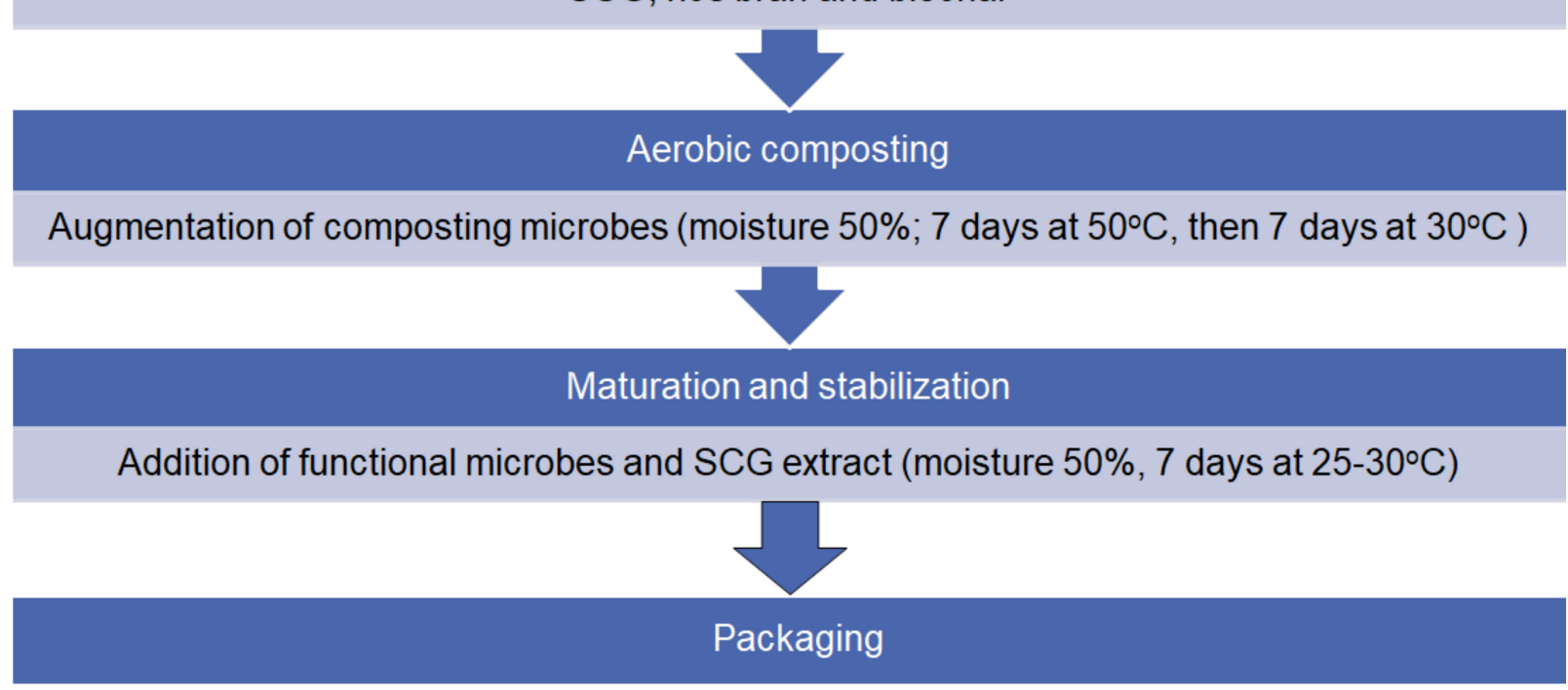

Figure 1. Manufacturing process of the functional composts using SCGs, rice bran, biochar, and functional microbes.

\subsection{Microbial Community Analysis of the Manufactured Complete Composts}

The microbial community structures in the composts were analyzed using 16S rRNA gene-based pyrosequencing, since various microbial communities were involved in the composting process. The detailed analysis procedures were described by Kim et al. (2014) [33]. In brief, the total bacterial genomic DNA of each compost was isolated using a PowerSoil ${ }^{\circledR}$ DNA Isolation Kit (Mo Bio Laboratories, Inc., Carlsbad, CA, USA). Variable regions (V1-V3) of the bacterial 16S rRNA gene were then amplified from the genomic DNA, and the library construction, sequencing, and all subsequencing analyses were performed using a $454 \mathrm{GS}$ FLX Junior Sequencing System (Roche, Brandford, CT, USA) and the accompanying protocols. Statistical analyses of microbial communities were accomplished with the Mothur program, using a 3\% difference cut-off value (Schloss et al., 2009). Principal coordinate analysis (PCoA) and fast Unifrac analysis were conducted using CLcommunity software (Chunlab, Inc., Seoul, Korea).

\subsection{Crop Growth Conditions for Test of the Manufactured Composts}

As a part of the efficacy test of the complete composts, the effects of the composts on the growth of commercial crops such as pepper were studied on the laboratory scale (Table 2). The growth test was performed using a round plastic pot (upper diameter $15 \mathrm{~cm}$, lower diameter $10 \mathrm{~cm}$, and height $12 \mathrm{~cm}$ ) carrying universal potting soil composed of peat (Gramoflor $\mathrm{GmbH}, \mathrm{KG}$, Vechta, Germany) $(1.2 \mathrm{~kg})$ under ambient indoor conditions ( $25^{\circ} \mathrm{C} ; 300-500$ lux sunlight). Commercial organic fertilizer (Coffee Microbial Fertilizer, KT Trade Inc., Seoul, Korea) and chemical fertilizer (All Purpose Compound Fertilizer, Nousbo Inc., Suwon, Korea; $100 \mathrm{~g} / \mathrm{m}^{2}$ ) were amended according to the manufacturer's recommendations for the duration of the experiment, whereas the manufactured compost was amended once in the beginning of the experiment. Each amendment was conducted in triplicate pots, each of which was planted with three seedlings of pepper, and the growth experiment lasted 2 weeks. The growth effect was examined for the three representative plants in each pot, and leaf length and leaf width of the second branch from the crown top were measured weekly for 17 days, and perfectly grown leaves were taken for the analysis of antioxidant production. 
Table 2. Conditions for pepper plants for the test of growth and antioxidant production by treatment of functional compost in pots.

\begin{tabular}{|c|c|c|c|c|}
\hline $\begin{array}{l}\text { Treatment } \\
\text { Code }\end{array}$ & $\begin{array}{c}\text { Kinds of Compost or } \\
\text { Fertilizer }\end{array}$ & $\begin{array}{l}\text { SB Cultures } \\
(\%, w / w) *\end{array}$ & $\begin{array}{l}\text { St-3 Culture } \\
(\%, w / w)^{* *}\end{array}$ & $\begin{array}{c}\text { Compost or } \\
\text { Fertilizer } \\
\text { Amount (g) }\end{array}$ \\
\hline PT_1C & NC & 0 & 0 & 24 \\
\hline PT_1 & Tr_1 & 1.0 & 1.0 & 24 \\
\hline PT_- $2 \mathrm{C}$ & Tr_2 & 0 & 0 & 24 \\
\hline PT_2 & Tr_3 & 1.0 & 1.0 & 24 \\
\hline PT_3C & Tr_4 & 0 & 0 & 24 \\
\hline PT_3 & Tr_5 & 1.0 & 1.0 & 24 \\
\hline PT_4 & Commercial compost product & - & - & 9.0 \\
\hline PT_5 & Chemical fertilizer & - & - & 1.54 \\
\hline
\end{tabular}

* Bacillus cereus SB-3 KCTC14418BP and Bacillus toyonensis SB-4 KCTC14417BP; ${ }^{* *}$ Streptomyces sasae St-3.

\subsection{Analysis of Antioxidants from Leaves of Pepper Plants Grown on the Composts}

To determine DPPH radical scavenging activity, $1 \mathrm{~g}$ of dried pepper leaves and fruits was used to extract and prepare a sample solution for the antioxidant test. The assay of 1,1diphenyl 2-picryl-hydrazyl (DPPH) radical scavenging activity was performed following the methods in a previous report [34]. Briefly, $1 \mathrm{~mL}$ of ethanol extract and $5 \mathrm{~mL}$ of a freshly prepared DPPH ethanol solution $(0.1 \mathrm{mM})$ were mixed thoroughly and kept in the dark. After $30 \mathrm{~min}$ of incubation at ambient temperature, the absorbance was read against a blank at $517 \mathrm{~nm}$ by using a UV-visible spectrophotometer (Model POP, Optizen, Inc., Seoul, Korea). The percentage of free radical scavenging activity was calculated as follows: scavenging activity $(\%)=(1-($ A517 $\mathrm{nm}$ of sample $/$ A517 $\mathrm{nm}$ of blank $)) \times 100$.

The total phenolic content as an antioxidant material was determined by the FolinCiocalteu method using gallic acid as the standard following the methods in a previous report [34]. The extract was prepared from $1 \mathrm{~g}$ of dried and macerated leaf or fruit with the incubation time of $24 \mathrm{~h}$ and filtered. The ethanol extract solution was shaken for $1 \mathrm{~min}$ with $0.4 \mathrm{~mL}$ of Folin-Ciocalteu reagent $(1 \mathrm{M})$ and mixed with $0.8 \mathrm{~mL}$ of $\mathrm{Na}_{2} \mathrm{CO}_{3}(20 \%$, $w / v)$. After $8 \mathrm{~min}$ of incubation, the mixture was centrifuged at $15,000 \times g$ for $10 \mathrm{~min}$. The absorbance of the supernatant was measured at $730 \mathrm{~nm}$ using a spectrophotometer. The results are expressed as milligrams of gallic acid equivalent per gram of extract (mg GAE/g) based on the standard curve for gallic acid concentration versus absorbance $(R=0.873)$ [34]

The total flavonoid content was determined following the method of Park et al. (2008) [35]. In a $10 \mathrm{~mL}$ test tube, $0.3 \mathrm{~mL}$ of extract, $3.4 \mathrm{~mL}$ of $30 \%$ methanol, $0.15 \mathrm{~mL}$ of $\mathrm{NaNO}_{2}(0.5 \mathrm{M})$, and $0.15 \mathrm{~mL}$ of $\mathrm{AlCl}_{3} \cdot 6 \mathrm{H}_{2} \mathrm{O}(0.3 \mathrm{M})$ were mixed. After $5 \mathrm{~min}, 1 \mathrm{~mL}$ of $\mathrm{NaOH}(1 \mathrm{M})$ was added. The solution was mixed well, and the absorbance was measured against the reagent blank at $506 \mathrm{~nm}$. The standard curve for total flavonoids was obtained using rutin standard solution $(0$ to $100 \mathrm{mg} / \mathrm{L}$ ) under the same procedure described earlier. The total flavonoids were expressed as milligrams of rutin equivalents per gram of dried fraction.

For TEAC analysis, the ABTS reagent was prepared by mixing equal amounts of aqueous $7.4 \mathrm{mM}$ ABTS and $2.6 \mathrm{mM}$ potassium persulfate solutions, which were allowed to react overnight in the dark [36]. Trolox standard solution was prepared, and absorbance was recorded on the UV-visible spectrophotometer (Model POP, Optizen Inc., Seoul, Korea) at $730 \mathrm{~nm}$.

\subsection{Inhibition Effects of Streptomyces sasae St-3 on Root Rot Plant Pathogens in Petri Dishes and Pots}

The inhibitory effect of the isolated strain St-3 on phytopathogens Pythium ultimum (KACC 40705) and Fusarium oxysporum f. sp. lactucae (KACC 42795) was analyzed based on radish germination activity and its seedling growth activity (Table 3 ). The experiment was accomplished by growing 20 radish seeds on a sterilized filter paper soaked with $2 \mathrm{~mL}$ of compost extract of Tr_4 within a petri dish in which Streptomyces sasae St-3 and the pathogen cultures were inoculated. 
Table 3. Experimental conditions for determining the inhibition effect of Streptomyces sasae St-3 on plant pathogens against radish germination in the presence of the functional compost extract using petri dishes.

\begin{tabular}{ccccc}
\hline Treatment Code & Treatment & Compost Extract & $\begin{array}{c}\text { Inoculation of } \\
\text { Streptomyces sasae* St-3 }\end{array}$ & Root Rotting Pathogen ** \\
\hline CPP & Control & $\mathrm{Tr}_{-} 4$ & - & Pythium ultimum \\
TPP & Treatment & $\mathrm{Tr} \_4$ & + & Pythium ultimum \\
CPF & Control & $\mathrm{Tr} \_4$ & - & Fusarium oxysporum f. lactucae \\
TPF & Treatment & $\mathrm{Tr} \_4$ & + & Fusarium oxysporum $\mathrm{f}$. lactucae \\
\hline
\end{tabular}

${ }^{*}$ Grown on SCG extraction solution $\left(10 \%, w / w ; 121^{\circ} \mathrm{C}\right.$ for $\left.15 \mathrm{~min}\right) ;{ }^{* *}$ grown in ISP-4 medium.

The inhibitory effect of strain St-3 on the same phytopathogens was also analyzed using pots carrying $1.2 \mathrm{~kg}$ of universal potting soil composed of peat (Gramoflor $\mathrm{GmbH}$, KG, Vechta, Germany) and $24 \mathrm{~g}$ of the manufactured compost (Tr_4). Each pot carried 4 pepper plants infected with the root rot plant pathogens Fusarium oxysporum f. sp. lactucae (KACC 42795) and Pythium ultimum (KACC 40705) (Table 4).

Table 4. Effects of the potential plant growth-promoting bacteria (Bacillus cereus SB-3 and Bacillus toyonensis SB-4) and the pathogen-inhibiting bacterium (Streptomyces sasae St-3) on pepper plants infected with the root rot plant pathogens Fusarium oxysporum f. sp. lactucae (KACC 42795) and Pythium ultimum (KACC 40705) in the pot soil.

\begin{tabular}{cccc}
\hline Treatment Code & $\begin{array}{c}\text { Compost } \\
\text { Amended }\end{array}$ & $\begin{array}{c}\text { Inoculation of St-3, } \\
\text { SB-3, and SB-4 * }\end{array}$ & Root Rotting Pathogen ** \\
\hline Tr_4 & $\operatorname{Tr}$ _4 & + & - \\
Tr_5 & $\operatorname{Tr} 55$ & + & - \\
Tr_4_PU & $\operatorname{Tr}$ _4 & - & Pythium ultimum \\
Tr_5_PU & $\operatorname{Tr} 55$ & + & Pythium ultimum \\
Tr_4_FO & $\operatorname{Tr}$ _4 & - & Fusarium oxysporum $\mathrm{f}$. lactucae \\
Tr_5_FO & $\operatorname{Tr}$ _5 & + & Fusarium oxysporum $\mathrm{f}$. lactucae \\
\hline${ }^{*}$ Grown on SCG extraction solution $\left(10 \%, w / w ; 121^{\circ} \mathrm{C}\right.$ for $\left.15 \mathrm{~min}\right) ;{ }^{* *}$ grown on ISP-1 medium.
\end{tabular}

\subsection{Statistical Analysis}

The data from the experiments were subjected to analysis of variance for a completely random design using SPSS statistical software [37]. The data are presented as the mean \pm standard deviation of duplicate or triplicate determinations according to the test and treatment. Comparison of means was analyzed by a t-test calculated in MS Excel and Duncan's test using the SPSS system (IBM SPSS statistics 19), and differences were considered significant when $p$ was $<0.05,<0.01$, or $<0.001$.

\section{Results}

3.1. Isolation and Selection of Plant Growth-Promoting Bacteria and Plant Pathogen-Inhibiting Bacteria, and Their Growth Medium Preparation from Spent Coffee Ground

Six Bacillus sp. strains (SB-1, SB-2, SB-3, SB-4, SB-5, and SB-6) and one strain of actinomycetes (St-3) were isolated from the forest soils at the Korea Maritime and Ocean University. The Bacillus sp. strains were tested for their potential plant-growth-promoting function, and the actinomycetes strain was tested for its suppression of plant pathogens (Figures 2 and 3 ). For the experiment, the bacteria were inoculated and selected according to the previous result. The selected bacteria, SB-3, SB-4, SB-6, and SB (1-6) (mixed), in SCG extract, and SB-3 and SB-4 showed high rates for radish (Figure 2a,b), while the growth of pepper was relatively inhibited under the same experimental conditions (Figure 2d). This appeared to be due to the sensitivity of pepper seedlings to the SCG extraction medium compared to the radish medium. Strain St-3 was observed to effectively inhibit the growth of the root rot fungi such as Fusarium oxysporum f. sp. lycopersici (KACC 40032) (Figure 3a), Fusarium oxysporum f. sp. lactucae (KACC 42795) (Figure 3b), Pythium ultimum (KACC 40705) (Figure 3c), and Pythium sp. (KACC 40581) (Figure 3d). Microbial identification was 
performed for the finally selected three strains (SB-3, SB-4, and St-3) based on $16 \mathrm{~S}$ rDNA sequencing analysis and were identified as Bacillus cereus SB-3 (KCTC14418BP), Bacillus toyonensis SB-4 (KCTC14417BP), and Streptomyces sasae St-3 (KCTC14416BP), respectively.

(a)

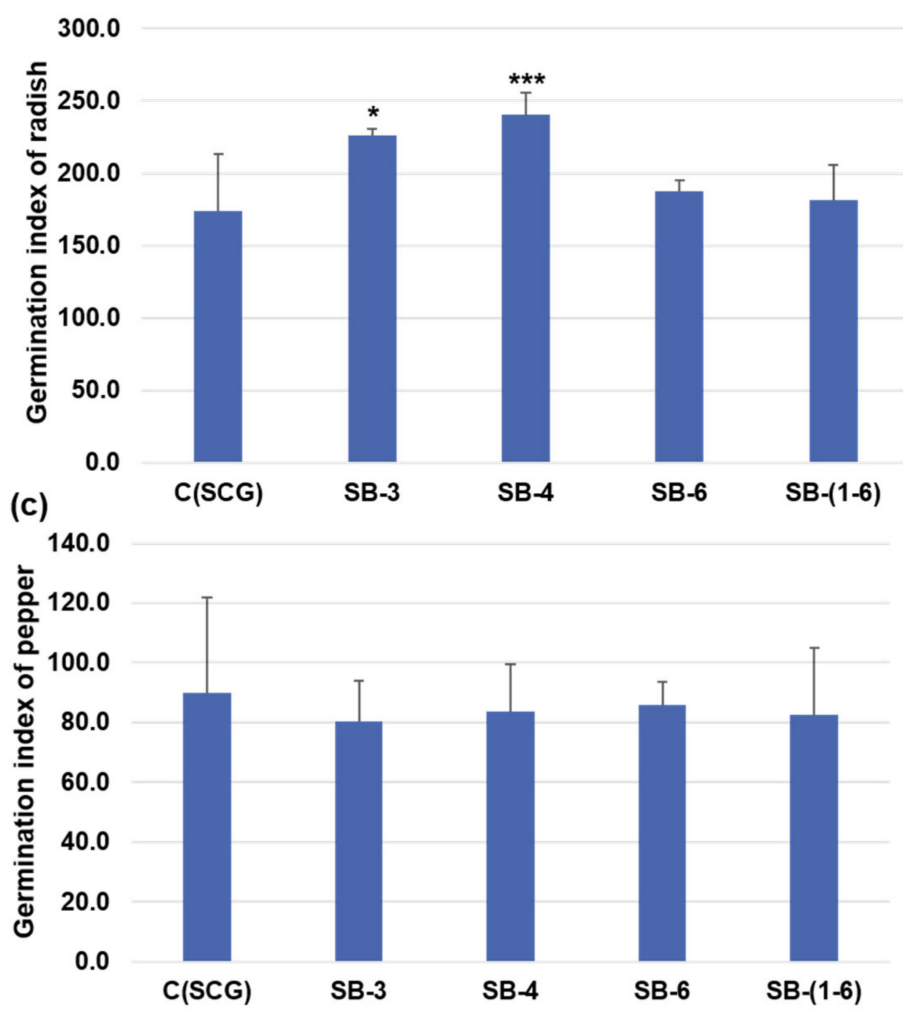

(b)
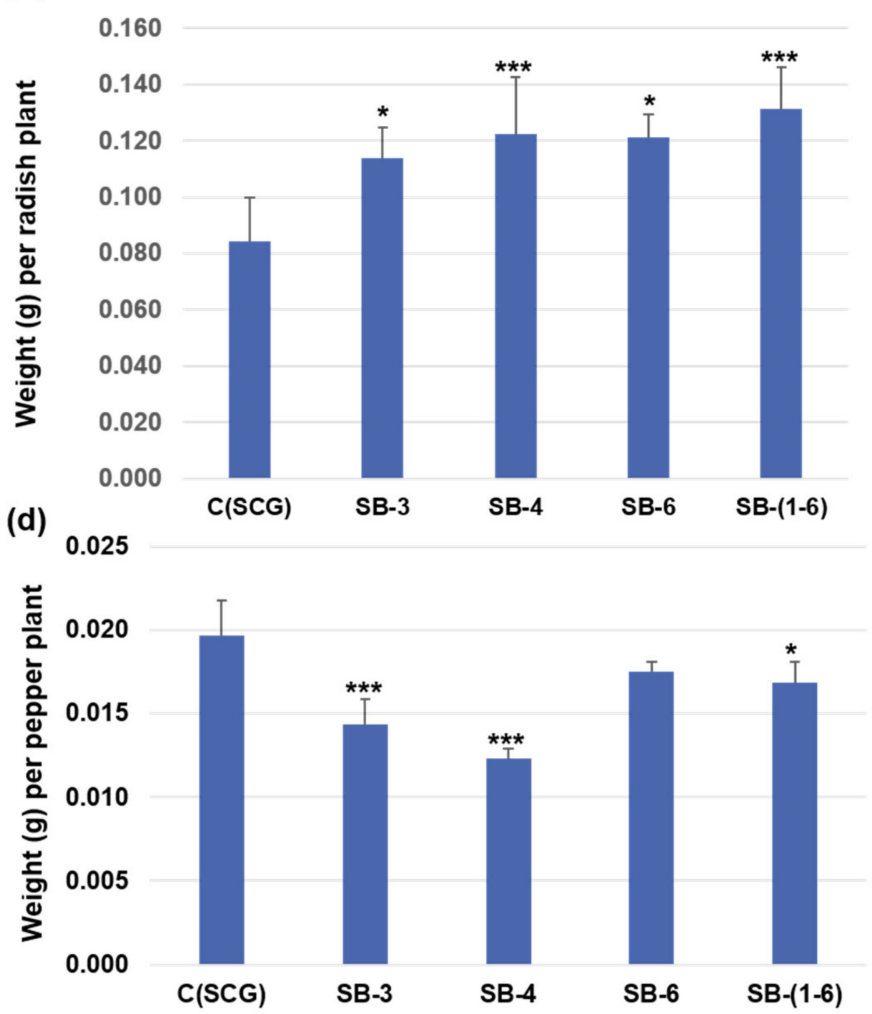

Figure 2. Effects of potential plant growth-promoting bacteria grown on SCG extract on the growth of radish plant (a,b) and pepper plant (c,d). SB-(1-6) indicates the mixed culture of strains SB-1, SB-2, SB-3, SB-4, SB-5, and SB-6. * indicates the significance of the treatment comparing with the control; ${ }^{*}-p<0.05 ;{ }^{* * *}-p<0.001$.

The phytopathogens Fusarium oxysporum f. sp. lycopersici (KACC 40032), Fusarium oxysporum f. sp. lactucae (KACC 42795), Pythium ultimum (KACC 40705), and Pythium sp. (KACC 40581) were highly suppressed by Streptomyces sasae St-3 in three days of incubation at $30{ }^{\circ} \mathrm{C}$ (Figure 3). The growth and the colony size of St-3 was unique between the two different inoculated pathogens. The fungi were spread throughout the plates on day one, and St-3 dominated with its growth, which suppressed the entire part where the St-3 was streaked. The St-3 culture was analyzed and confirmed under a microscope. The bacteria were separately cultured and stored at $4{ }^{\circ} \mathrm{C}$ for further analyses. 
(a)

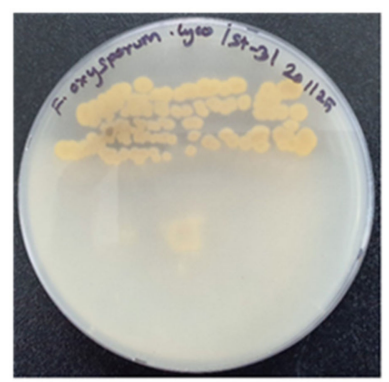

(b)

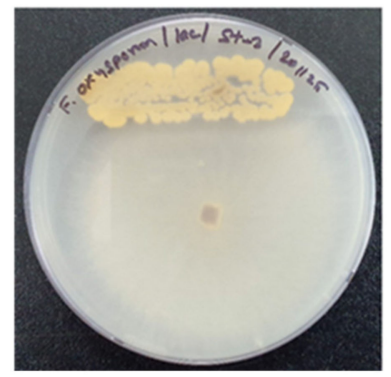

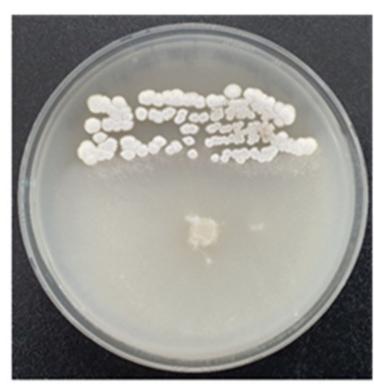

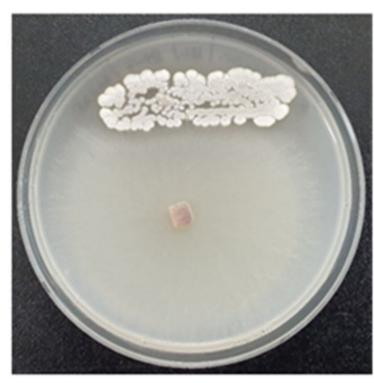

(c)
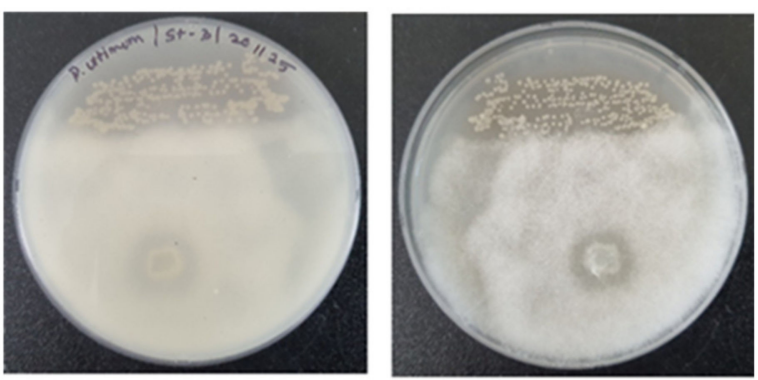

(d)

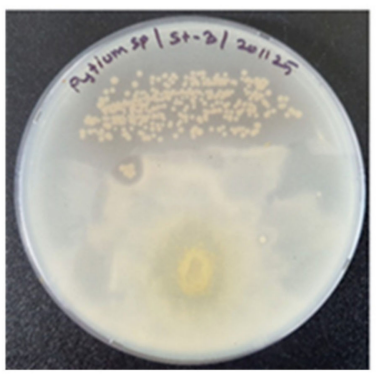

Figure 3. Analysis of the inhibitory effect of Streptomyces sasae St-3 on phytopathogens (Fusarium oxysporum f. sp. lycopersici (KACC 40032) (a), Fusarium oxysporum f. sp. lactucae (KACC 42795) (b), Pythium ultimum (KACC 40705) (c), and Pythium sp. $(\operatorname{KACC} 40581)(\mathbf{d}))$.

\subsection{Impacts of the Various SCG Extracts on the Growth of Potential Plant Growth-Promoting Bacteria}

The potential plant growth promoting bacteria (SB-3 and SB-4) selected from phytotoxicity analysis were tested to find their growth status in the three different media (Figure 4 ). The extraction of SCGs using distilled water by heat treatment at $121^{\circ} \mathrm{C}$ for $15 \mathrm{~min}$ showed the highest CFU / mL of each culture of both bacteria. The SGC media extracted with $80 \%$ ethanol at room temperature produced considerable growth of SB-3 with a $\log _{10} \mathrm{CFU} / \mathrm{mL}$ of 9.72, and a lower CFU/mL for SB-4. SB-3 (A) and SB-4 (A) showed higher population densities $\left(\log _{10} \mathrm{CFU} / \mathrm{mL}=9.72\right.$ and 9.99, respectively) compared to those grown in other extracts. The extraction of SCGs using distilled water by a shanking incubator (150 rpm) at $25{ }^{\circ} \mathrm{C}$ for one hour produced a somewhat high CFU/mL with SB-3, whereas SB-4 was hardly observed in the plates due to indigenous bacterial contamination from the spent coffee grounds. Therefore, SCG extraction $\left(10 \%, w / w\right.$ in water) by heat treatment $\left(121^{\circ} \mathrm{C}\right.$ for $15 \mathrm{~min}$ ) may be commercially applicable to culturing plant-growth-promoting bacteria.

3.3. Composting Process Monitoring, Physico-Chemical Analysis, and Maturity Quality Test of the Manufactured Composts

The temperature and moisture content were monitored for the composting treatments. A total of $1.2 \mathrm{~kg}$ of substrate mixture $\left(\mathrm{NC}\right.$ and $\left.\operatorname{Tr} \_1\right)$ and $5 \mathrm{~kg}\left(\operatorname{Tr} \_2, \operatorname{Tr} \_3, \operatorname{Tr} \_4\right.$, and $\left.\operatorname{Tr} \_5\right)$ were composted, where the highest temperature reached was $55^{\circ} \mathrm{C}$, which then decreased to $30-36^{\circ} \mathrm{C}$. The temperatures were maintained during the whole 14 days of composting. The moisture content was adjusted every two days to $50-55 \%$ due to the high temperature. The quality control data of the functional composts manufactured are shown in Table 5. The representative composts ( $\operatorname{Tr} \_1$ and $\left.\mathrm{Tr} \_5\right)$ met all the commercial quality standards approved by the Office of Rural Development of the South Korean government. Tr_5 carried higher contents of organic matter, total phosphorus, and total potassium than Tr_1, probably due to the significantly higher content of rice bran in Tr_5. 


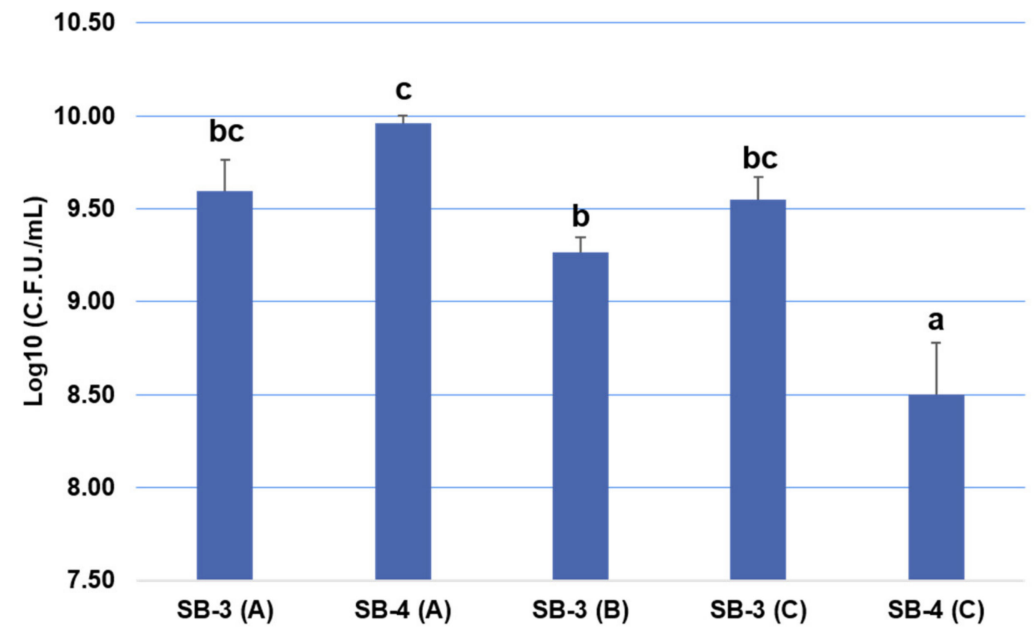

Figure 4. Effects of various SCG extracts on the growth of potential plant growth-promoting bacteria. (A) SCG in distilled water $(10 \%, w / w)$ and extracted by heat treatment $\left(121^{\circ} \mathrm{C}\right.$ for $\left.15 \mathrm{~min}\right)$; (B) SCG in distilled water $(10 \%, w / w)$ and extracted by a shaking incubator $(150 \mathrm{rpm})$ at $25^{\circ} \mathrm{C}$ for $1 \mathrm{~h}$; (C) SCG suspended in $80 \%$ ethanol $(10 \%, w / w)$ and extracted by a shaking incubator $(150 \mathrm{rpm})$ at $25^{\circ} \mathrm{C}$ for $1 \mathrm{~h}$. Letters above the error bar indicates the comparison of samples using Duncan's test.

Table 5. Quality control data of the functional composts manufactured on the laboratory and pilot scales using SCGs, rice bran, biochar, and functional microbes *.

\begin{tabular}{ccccc}
\hline $\begin{array}{c}\text { Evaluation } \\
\text { Criteria }\end{array}$ & Unit & $\begin{array}{c}\text { Commercial } \\
\text { Quality Standard }\end{array}$ & Tr-1 & Tr-5 \\
\hline $\begin{array}{c}\text { Organic } \\
\text { matter/N ratio }\end{array}$ & & $<45$ & 19.68 & 26 \\
$\mathrm{NaCl}$ & $\%$ & $<2.0$ & 0.051 & 0.042 \\
Moisture & $\%$ & $<55$ & 45.08 & 29.08 \\
$\mathrm{As}$ & $\mathrm{mg} \mathrm{kg}^{-1}$ & $<45$ & $\mathrm{ND}$ & $\mathrm{ND}$ \\
$\mathrm{Cd}$ & $\mathrm{mg} \mathrm{kg}^{-1}$ & $<5$ & $\mathrm{ND}$ & $\mathrm{ND}$ \\
$\mathrm{Hg}$ & $\mathrm{mg} \mathrm{kg}^{-1}$ & $<2$ & $\mathrm{ND}$ & $\mathrm{ND}$ \\
$\mathrm{Pb}$ & $\mathrm{mg} \mathrm{kg}^{-1}$ & $<130$ & 0.2 & 0.04 \\
$\mathrm{Cr}$ & $\mathrm{mg} \mathrm{kg}^{-1}$ & $<200$ & 2.35 & 1.75 \\
$\mathrm{Cu}$ & $\mathrm{mg} \mathrm{kg}^{-1}$ & $<360$ & 43.8 & 16.27 \\
$\mathrm{Ni}$ & $\mathrm{mg} \mathrm{kg}^{-1}$ & $<45$ & 2.36 & 1.05 \\
$\mathrm{Zn}$ & $\mathrm{mg} \mathrm{kg}^{-1}$ & $<900$ & 49.3 & 61.99 \\
Organic matter & $\%$ & $>30$ & 49.6 & 62.68 \\
E. coli O157:H7 & $\mathrm{ND}$ & $\mathrm{ND}$ & $\mathrm{ND}$ & $\mathrm{ND}$ \\
Salmonella & $\mathrm{ND}$ & $\mathrm{ND}$ & $\mathrm{ND}$ & $\mathrm{ND}$ \\
$\mathrm{Maturity}$ & Instrument analysis & Complete & Complete & Complete \\
HCl insoluble & $($ CoMMe-100) & humification & humification & humification \\
material & $\%$ & $<25$ & 0.34 & 0.27 \\
Total N $(\%) * * *$ & & - & 2.52 & 2.41 \\
Total P $(\%) * * *$ & & - & 1.22 & 3.36 \\
Total K $(\%) * * *$ & & - & 0.89 & 1.66 \\
\hline
\end{tabular}

* The analysis was performed by AT Analysis Center Co., Ltd., Incheon, Korea, and was officially approved by the Office of Rural Development, a part of the South Korean government; ND, no detection; ** Soiltek, Inc., Jeju, Korea; ${ }^{* * *}$ not included in the official evaluation criteria.

To analyze the physio-chemical properties and maturity quality, we performed a phytotoxicity test. The composts were diluted ten times, and the germination index and the weight of the grown plants were monitored using radish and pepper plants. The germination index of Tr_5 was $49 \%$ higher than the NC and 5.6\% higher than Tr_4. The addition of SB cultures and St-3 might be the reason for the enhancement in GI in Tr_5. The bioaugmented Tr_5 was higher in radish plant weight by $58 \%$, and $48 \%$ higher in pepper 
plant weight compared to NC. Tr_3 was significantly higher than the NC in both plants. TR_4 dominated in pepper plant by $88 \%$ and was $10.9 \%$ higher than the NC and Tr_5. Even though the ratio of $\operatorname{Tr} \_2$ and $\operatorname{Tr} \_3$ was similar to that of $\operatorname{Tr} \_4$ and $T r \_5$, composting in the laboratory (Tr_2 and $\operatorname{Tr} \_3$ ) and pilot $\left(\operatorname{Tr} \_4\right.$ and $\left.T r \_5\right)$ scales was clearly differentiated by the higher values for pilot-scale composting (Figure 5).

(a) 350.0

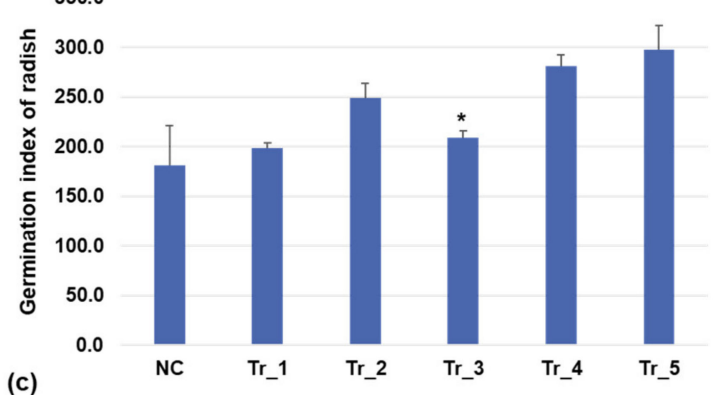

(c)

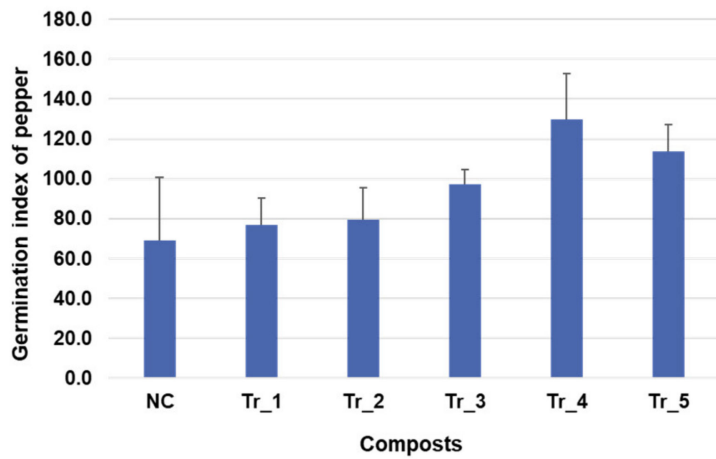

(b)

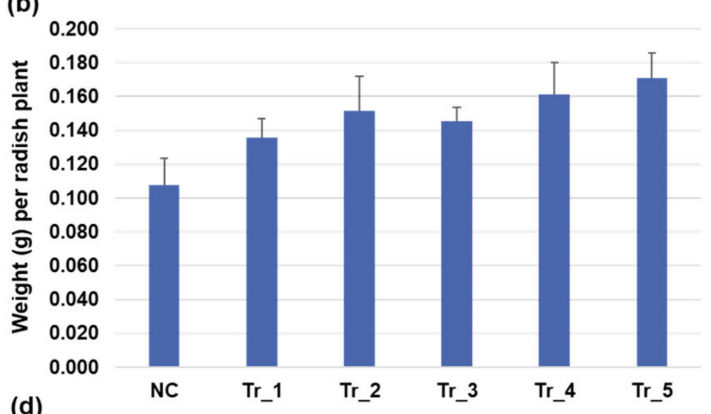

(d)

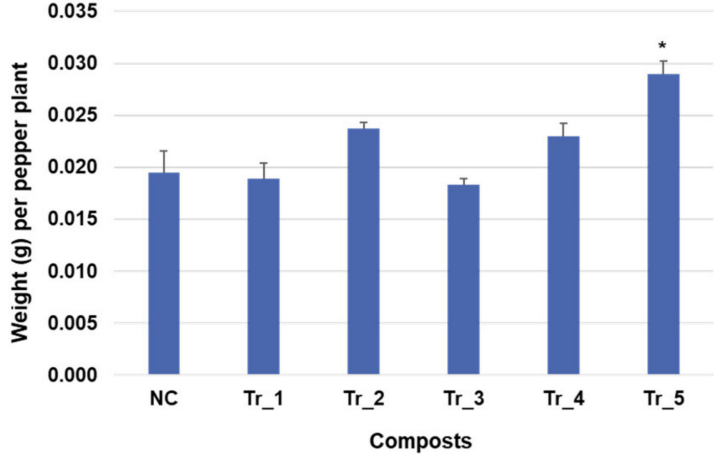

Figure 5. Effects of the functional composts on the growth of radish plants $(\mathbf{a}, \mathbf{b})$ and pepper plants $(\mathbf{c}, \mathbf{d})$. NC, Tr_2, and Tr_4 were the controls for $\operatorname{Tr} \_1, \operatorname{Tr} \_3$, and $\operatorname{Tr} \_5$, respectively; * indicates the significance of the treatment comparing with the control; $*-p<0.05$.

\subsection{Microbial Community Analysis of the Manufactured Composts}

The microbial community analysis was compared between the control and the treatments on the laboratory and pilot scales. The integrated samples Tr_2 and Tr_3 were excluded due to their low effectiveness. Sphingobacteriaceae_uc and B. multivorons were highly dominant in both NC and Tr_1. The B. coagulans group, B. thermoamylovorans group, and O. oleidegradans were comparatively higher in $\operatorname{Tr} \_1$ with $19 \%$ of the distribution. Most of the dominant species were lower in $\mathrm{Tr}$-1 compared to the NC, except the B. coagulans group because of the addition of SB and St-3 cultures (Figure 6a). Halotalea_uc was dominant in both $\operatorname{Tr} \_4$ and $\operatorname{Tr} \_5$. P. agglomerans and P. septica were dominant in $T r \_4$, and C. nuruki and L. acidipiscis in Tr_5. Halotalea_uc was the dominant species commonly present in all the samples, covering $40-50 \%$ of the distribution in $\operatorname{Tr} \_4$ and $\operatorname{Tr} \_5$ (Figure 6b). Even though we applied the same ingredients for the laboratory and pilot scales, the distribution of the microbial communities differed. The ratio of the substrates used in the composting and its processing environment might be the reason for the dominance of different microorganisms. 
(a) 30

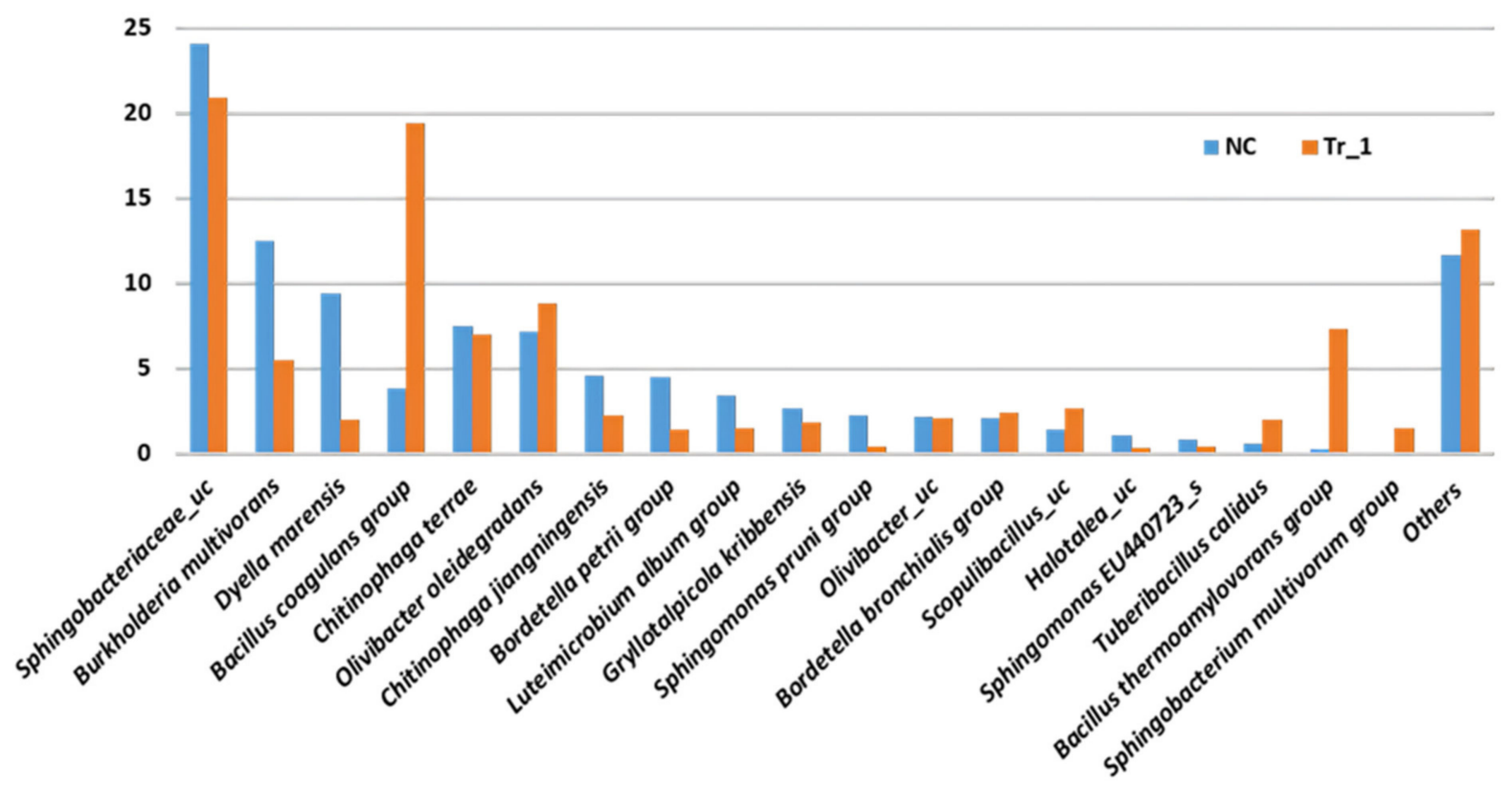

(b)

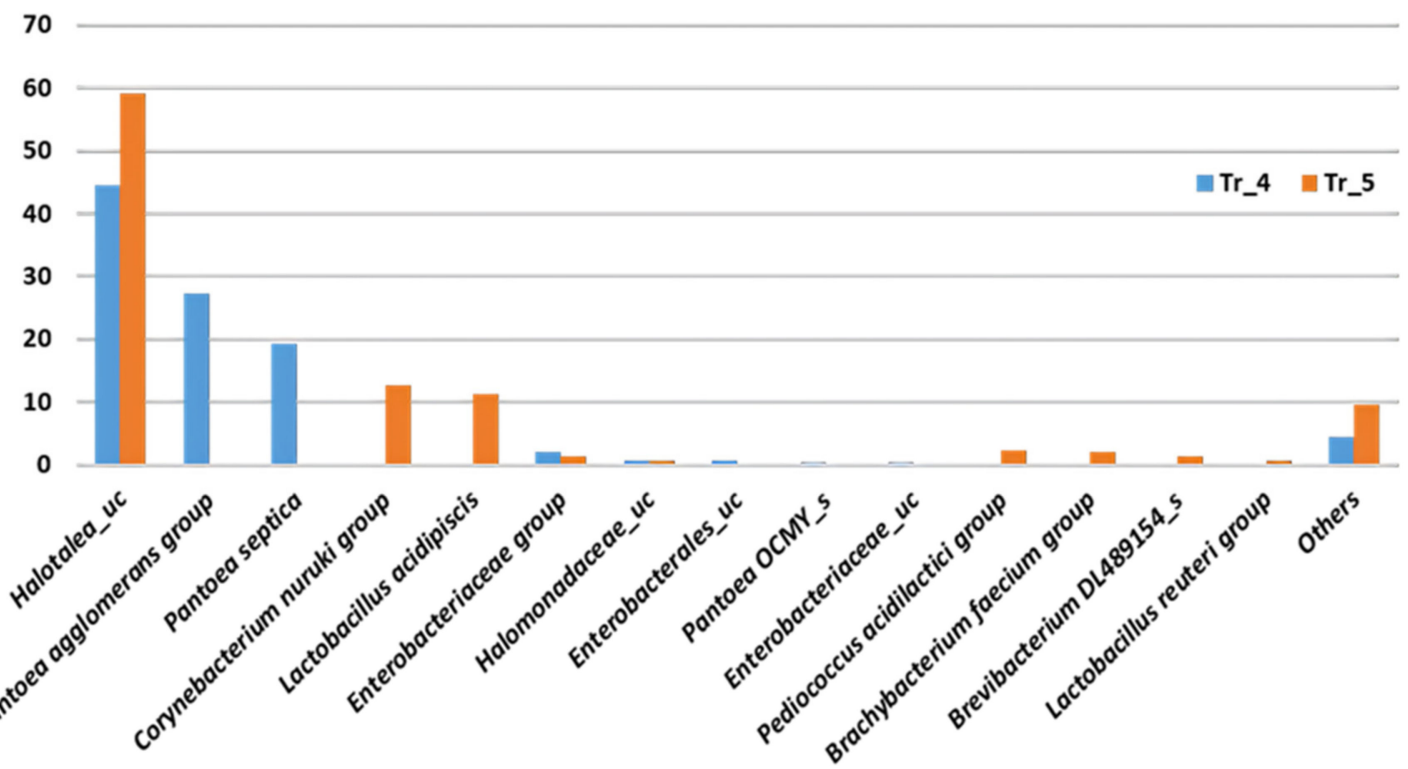

Figure 6. Microbial community structures of the representative functional composts. (a) Laboratory scale; (b) Pilot scale.

3.5. Analysis of Pepper Growth and Antioxidant Production by Treatment with Functional Composts in Pot Experiments

To perform the antioxidant tests, the pepper leaves of each treatment were dried, crushed, and extracted using $80 \%$ ethanol. The antioxidant properties were examined with three controls of different composts with three treatments including commercial organic and chemical fertilizer (PT-4 and PT-5) (Figure 7). There were generally no significant differences among the composting samples in terms of DPPH and TPC (Figure 7a,b). PT-1 was higher in TFC by $13.1 \%$ (Figure 7c), whereas PT-1 and PT-2 were higher in TEAC than their controls (PT-1C and PT-2C) by $36.2 \%$ and $32.5 \%$, respectively (Figure $7 \mathrm{~d}$ ). 
(a)

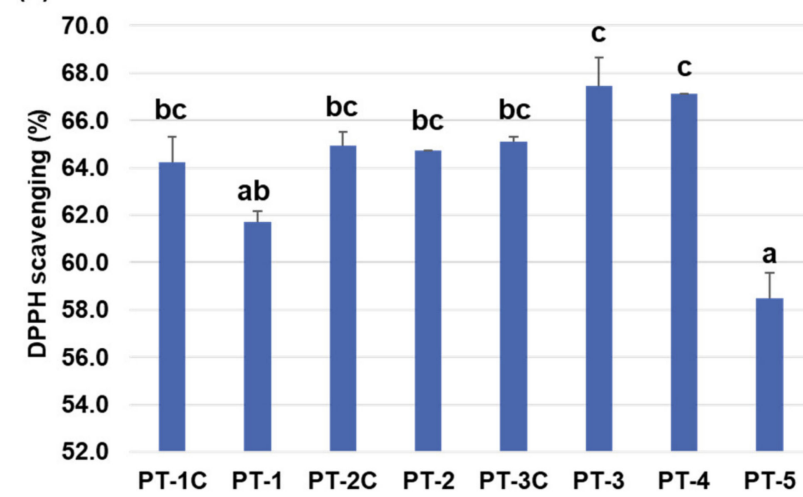

(c)

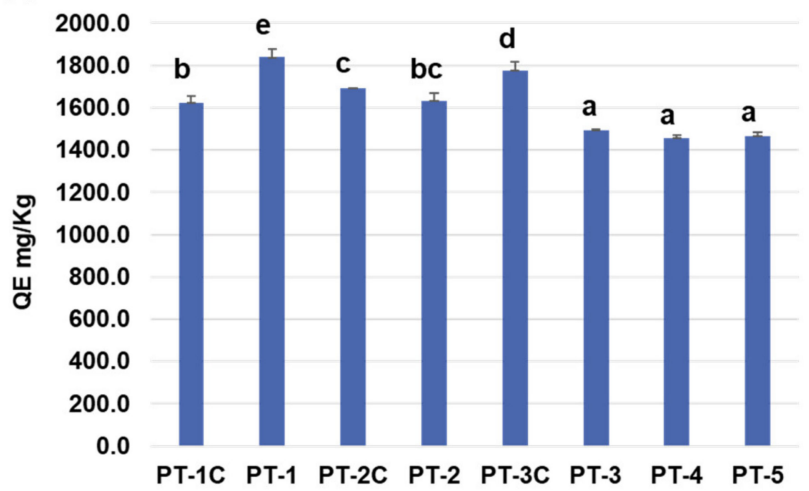

(b)

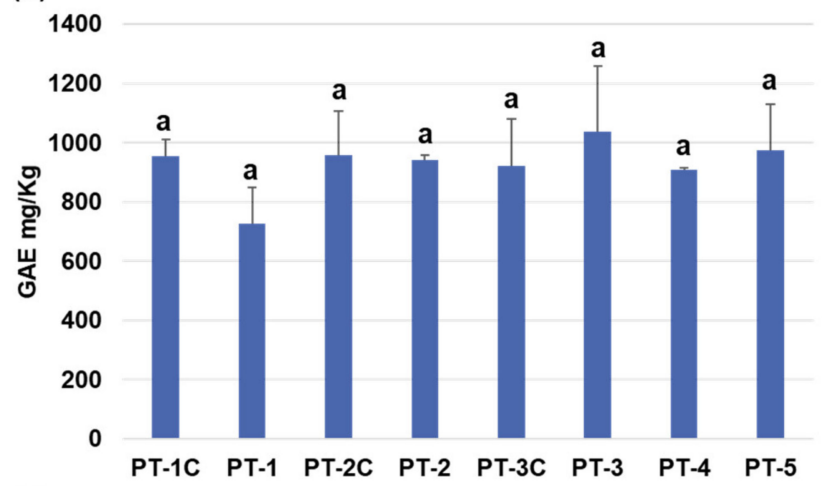

(d) 2500.0

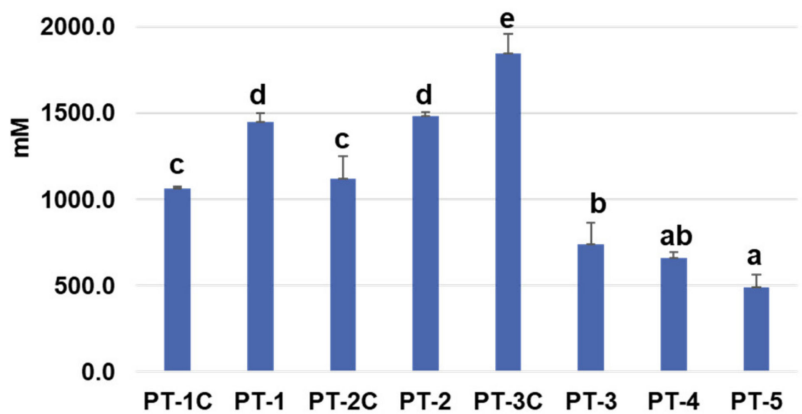

Figure 7. Antioxidant activity of leaf extracts of pepper plants grown in soil amended with SCG composts, commercial compost, and chemical fertilizer. The tests included (a) DPPH scavenging activity, (b) total phenolic content (TPC), (c) total flavanoid content (TFC), and (d) Trolox equivalent antioxidant activity (TEAC). Letters above the error bar indicates the comparison of samples using Duncan's test.

3.6. Inhibition Effect of Streptomyces Sasae St-3 on Plant Pathogens during Radish Germination in the Presence of Functional Compost Extract

The treatment with St-3 to the radish seeds infested with the fungal pathogens (P. ultimum and F. oxysporum) was compared to the control (infestation of the pathogens without St-3). The radish seedling growth in TPF was significantly higher than its control, CPF, by $12 \%$ (Figure $8 \mathrm{a}$ ). However, the radish germination index in TPP was significantly higher compared to CPP as the control (by 20\%) (Figure 8b).

(a)

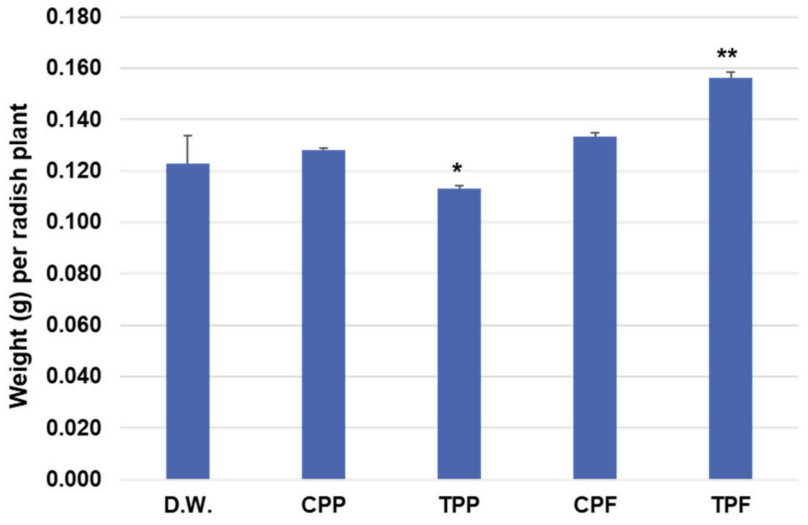

(b)

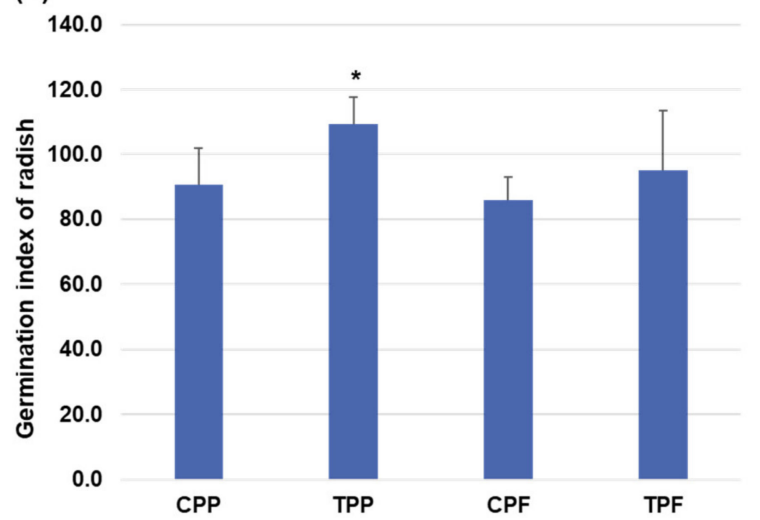

Figure 8. Inhibition effects of Streptomyces sasae St-3 on the root rot plant pathogens Pythium ultimum (KACC 40705) (TPP) and Fusarium oxysporum f. sp. lactucae (KACC 42795) (TPF), whose controls were CPP and TPP, respectively; (a) Weight per raddish plant, (b) Germination index of radish plant; ${ }^{*} p<0.05$ and ${ }^{* *} p<0.01$. 


\subsection{Effects of the Potential Plant Growth-Promoting Bacteria and Plant Pathogen-Inhibiting Bacterium on Pepper Plants Infected with Root Rot Plant Pathogens}

The antioxidant activity of leaf extracts of pepper plants grown in soil amended with the functional SCG composts carrying Streptomyces sasae St-3 and infected with root rot plant pathogens Fusarium oxysporum f. sp. lactucae (KACC 42795) (FO) and Pythium ultimum (KACC 40705) (PU) was determined (Figure 9). The total phenol content and TEAC in pepper plant leaves were significantly higher in $T r \_5$ than in the control (Tr_4) by $23.5 \%$ and $19.5 \%$, respectively, but there were no differences amongst all the treatments in the presence of the fungal pathogens (Figure 9b,d). Compared to the pathogen-treated samples (Tr_5-PU and Tr_5-FO), Tr_5 showed higher TPC, TFC, and TEAC activity (12-48\%). Moreover, we observed no differences in the total flavonoid content between Tr_4 and Tr_5 in the presence and absence of the fungal pathogens, whereas DPPH scavenging was significantly higher in the presence of the pathogen (Fusarium oxysporum f. sp. lactucae) (Figure 9c).

(a)
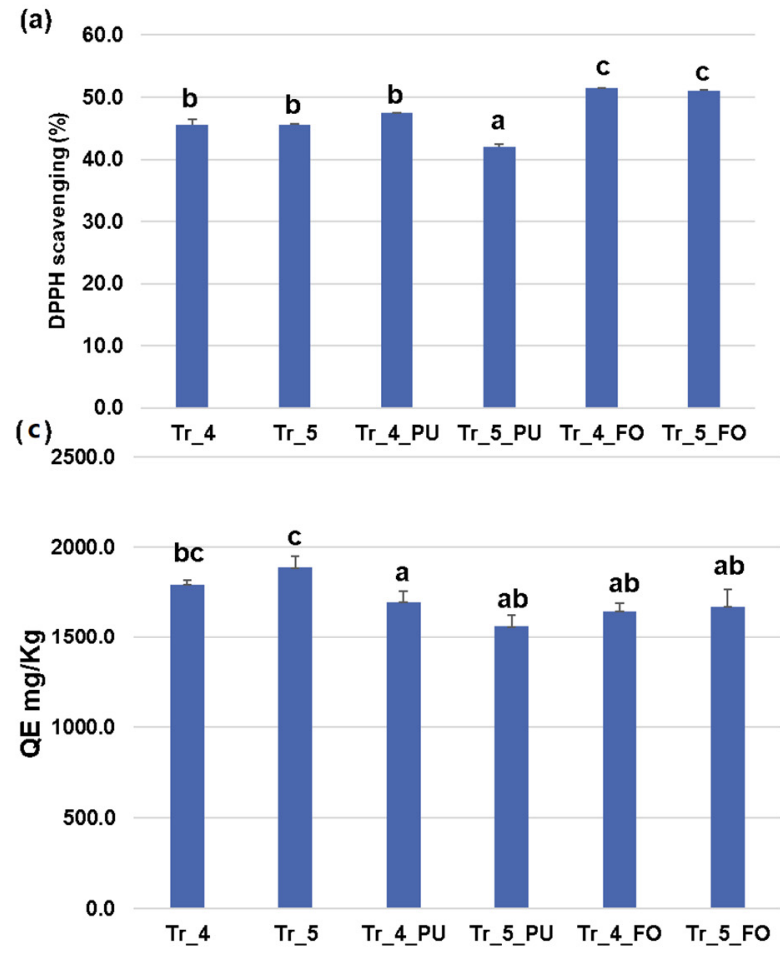

(b) 2500

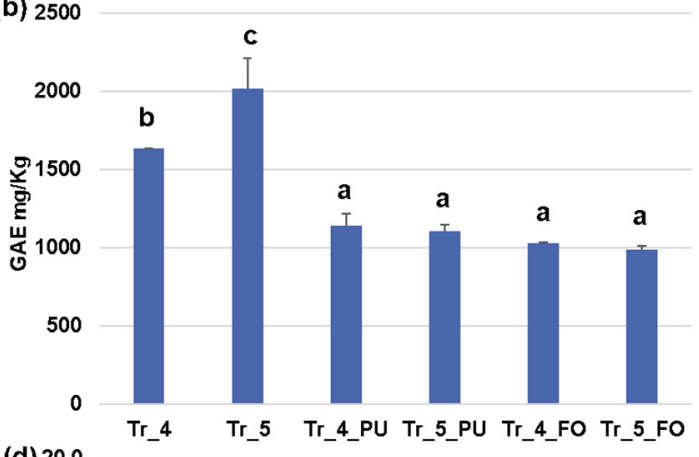

(d) 20.0

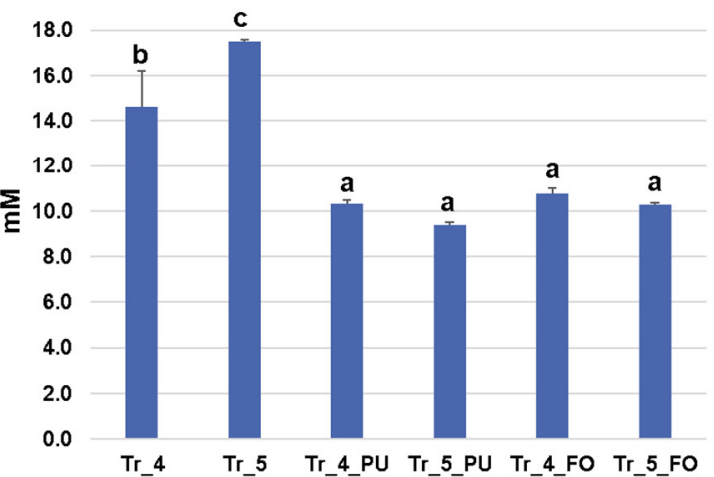

Figure 9. Antioxidant activity of leaf extracts of pepper plants grown in soil amended with the functional SCG composts carrying Streptomyces sasae St-3 and infected with root rot plant pathogens Fusarium oxysporum f. sp. lactucae (KACC 42795) (FO) and Pythium ultimum (KACC 40705) (PU). The tests included (a) DPPH scavenging activity, (b) total phenolic content (TPC), (c) total flavanoid content (TFC), and (d) Trolox equivalent antioxidant activity (TEAC). Letters above the error bar indicates the comparison of samples using Duncan's test.

\section{Discussion}

The germination index (GI) was used to evaluate the phytotoxic substances present in the compost, which is one of the most sensitive parameters that accounts for the low toxicity affecting root growth [38]. The Bacillus sp. strains were tested for their potential plant-growth-promoting function, and SB-3 and SB-4 were selected for the composting process. Bacillus sp. is known to enhance the availability of macro- and micronutrients in the soil and their uptake by host plants [39]. Enhancement in the maximum proximate chemical constituents including carbohydrate, proteins, dry matter, etc., was recorded by the application of Bacillus sp. Stefan et al. [39] identified the significant role of Bacillus isolates in the enhancement in essential amino-acid contents and other nutritive chemical constituents in food crops [40]. The seed germination and plant growth of radish and 
pepper plants are significantly influenced by the nutrients available in the soil. The results of the two different plants confirms the difference between the several potential microbes tested in this process (Figure 2). Plants absorb phosphorus (P) and nitrogen (N) from the soil through root transporters, but the bioavailable forms of $\mathrm{P}$ and $\mathrm{N}$ are limited in rhizospheres [41]. Bacillus sp. convert the complex form of essential nutrients, such as P and $\mathrm{N}$, to a simple available form that is used during uptake by plant roots [42,43]. Phosphate is involved in nucleic acid, phospholipid, and adenosine triphosphate (ATP) metabolism, among other metabolic pathways, in plant cells [44]. The secretion of phosphatases and organic acids from Bacillus sp. acidifies the surrounding environment to facilitate the conversion of inorganic phosphate into free phosphate [42], [45]. In this study, Bacillus cereus SB-3 (KCTC14418BP) and Bacillus toyonensis SB-4 (KCTC14417BP) appeared to promote the growth of radish. The genomic analysis of plant-associated B. cereus 905 showed that the genes related to plant-growth-promoting traits were highly conserved [46]. B. cereus SA1 inoculation increased the biomass, chlorophyll content, and chlorophyll fluorescence of soybean plants under normal and heat stress conditions. The SA1 strain can be used as a good temperature-tolerant candidate for the mitigation of heat stress damage in soybean plants and can be commercialized as a biofertilizer [45]. Bacillus toyonensis COPE52 was reported to produce indoleacetic acid and protease activity, and emit volatiles such as acetoin, 2,3-butanediol, and dimethyl disulfide as potential plant-growth-promoting mechanisms, leading to growth in biomass and chlorophyll content in blueberry plants [47]. B. toyonensis COPE52 also showed plant-growth-promoting activities including indole-3acetic acid (IAA), protease activity, and biofilm formation, as well as antifungal activity against Botrytis cinereal, even in saline conditions [48].

Analysis of the inhibitory effect of Streptomyces sasae St-3 on the plant pathogenic fungi revealed its potential antifungal activity (Figure 3). This acidophilic characteristic of Streptomyces sp. may help it to adapt to the soil conditions. Moreover, a recent study found that the antifungal activity of Streptomyces inhibits fungi including Fusarium oxysporum, Pythium apanidermatum, P. ultimum, Rhizoctonia solani, Sclerotium rolfsii, Sclerotinia minor, and S. sclerotiorum, and other soil-borne plant pathogens [49]. We also demonstrated that the growth of phytopathogens Fusarium oxysporum f. sp. lycopersici (KACC 40032), Fusarium oxysporum f. sp. lactucae (KACC 42795), Pythium ultimum (KACC 40705), and Pythium sp. (KACC 40581) were highly suppressed by Streptomyces sasae St-3 after three days of incubation at $30^{\circ} \mathrm{C}$. This confirms that St-3 is a potential candidate for targeted anti-fungal treatment for crops.

The in vitro antibiosis of Streptomyces violaceusniger G10 against Fusarium oxysporum f. sp. cubense race 4 was demonstrated by inhibition zones formed in the cross-plug assay plates [50]. The in vitro antagonistic effects against the pathogen appeared to be caused by the antifungal metabolites produced by strain G10 in liquid media, leading to swelling, distortion, and excessive branching of hyphae and inhibition of spore germination. The chitinase enzyme produced by Streptomyces griseorubens E44G might play a role as an antifungal agent against F. oxysporum f. sp. lycopersici, digesting the fungal cell wall composed of chitin [51]. Streptomyces sasae TG01 can inhibit the growth of phytopathogenic fungi Fusarium solani and Fusarium oxysporum by producing secondary metabolites including 2-methyl-1,3-dioxolane as the major constituent [52]. The two most effective bioactive root symbiont Streptomyces strains (H2 and H3) were selected based on in vitro petri plate seedling bioassays (IPSB), effectively controlling the damping-off disease caused by Pythium aphanidermatum as well as behaving as plant growth-promoting rhizobacteria able to increase the fresh and dry weight of tomato plants [53].

The use of SCGs extracts to grow beneficial bacteria may allow a circumvention of this by-product disposal, producing a negative environmental impact as well as resulting in the loss of a rich source of nutrients and bioactive compounds [54]. Recent research proved that Bacillus fermented SCGs extracts exhibited increased phenolic- and flavonoidrelated antioxidant activity [54]. A recent article reported that the GI of wheat seeds grown in the extract of the vermicomposted SCG $(10 \%, w / w)$ showed 205\% [55]. In this study 
the Bacillus sp. strains (SB-3 and SB-4) grown on the SCGs extracts $(10 \%, w / w)$ showed higher germination indices (GIs) (231\% and 246\%) (Figure 2a). This non-cytotoxic effect by coffee-derived extracts was correlated with the coffee roasting level and the presence of chlorogenic acids and melanoidins [56].

The moisture content of all the composts was adjusted to 50-55\% to maintain sufficient microbial activity for composting. Temperature, which is one of the key indicators of composting, determines the rate of many biological processes and plays a significant role in the evolution and succession of microbiological communities [57]. Rice bran addition in $\operatorname{Tr} \_4$ and $\operatorname{Tr} \_5(50 \%, w / w)$ generally enhanced the germination index and the growth of radish and pepper. Islam et al. [58] reported that the GI of radish seeds for compost with the chicken manure was $130 \%$. The GI of radish seeds for Tr_5 in this study was much higher (297\%). The n-hexane, acetone, and water-soluble fractions obtained from rice bran were more effective on seed germination [59]. The addition of biochar during the composting process provided some benefits by helping to retain useful nutrients in the biochar. Biochar can also favor the creation of humic acids over fulvic acids during the composting of the rice bran and can alleviate nitrogen loss in the mature composting products. The addition of biochar during composting reduced the time required to enter the thermophilic phase and helped generate a higher temperature and longer duration in the thermophilic stage [60].

At laboratory-scale composting, the Bacillus coagulans group, Bacillus thermoamylovorans group, and Olivibacter oleidegradans became dominant after the addition of functional microbes (strains SB-3, SB-4, and St-3). Bacillus coagulans and Bacillus thermoamylovorans were dominant in the thermophilic stage of composting and had a greater capacity to degrade less biodegradable, complex organic compounds such as lignocelluloses [61]. Olivibacter oleidegradans was isolated from a biofilter clean-up facility on a hydrocarbon-contaminated site, whereas Olivibacter composti sp. nov. was isolated from compost collected at a greenhouse (shih). At pilot-scale composting, the growth of Halotalea_uc, Corynebacterium nuruki, and Lactobacillus acidipiscis was facilitated by the addition of the functional microbes. Previous reports have mentioned that Sphingobacteriaceae and Halotalea were dominant species in functional compost [62]. Corynebacterium nuruki was isolated from an alcohol fermentation starter, which was a mixture of grains and various micro-organisms including mold, yeast, and bacteria (Shin). There was a significant dominance of members of the Lactobacillus genus (L. brevis, L. plantarum, L. oris, and L. johnsonii) and Lactobacillus acidipiscis as a minor species [63]. It appeared that Corynebacterium nuruki and Lactobacillus acidipiscis originated from the rice bran used for composting materials in this study. Recent findings proved that $B$. coagulans might produce specific enzymes such as nitrile hydratase, endoinulinase, and alkaline lipase used for electrotransformation and fermentation for composting [64]. Lactobacillus acidipiscis was reported as a compost bacterium to be linked with nitrogen metabolism and fermentation in compost [65].

PT-1 had a significantly higher TFC, whereas PT-1 and PT-2 demonstrated a higher level of TEAC compared to each control (Figure 7c,d). This indicated that inoculation with the functional microbes (SB-3, SB-4, and St-3) during the stabilization stage of the composting process can enhance the antioxidant components in pepper plants. DPPH and TPC showed much higher activity with the range of $60-70 \%$ of SCV and 700-1000 GAE mg/kg compared to the previous compost augmented with PGPB [66]. The high QE of PT-1 in the total flavonoid content and PT-1 and PT-2 in TEAC proved the dominance of antioxidant activity through the bioaugmented compost (Figure 7c,d). Flavonoids have hydroxyl groups that are functional in promoting free radical scavenging activity and ABTS chelation of metal ions, hence mediating antioxidant activities [67]. It was hypothesized that plant growth-promoting bacteria (PGPB) facilitate the production of non-enzymatic antioxidants and increase the availability of mineral nutrients. It was reported that PGPB also release/increase the availability of mineral elements such $\mathrm{Cu}, \mathrm{Fe}, \mathrm{Mn}, \mathrm{Zn}$, etc., to plants by chelation and acidification of soil [57]. Siderophore production may be a major feature of PGPB. It is essential for certain iron-sulfur complex enzymes and iron-containing proteins 
and plays a major role in plant growth by participating in the synthesis of chlorophyll. Evidence also shows that beneficial microbes can enhance plants' tolerance to adverse environmental conditions [68]. For example, due to the application of a potassium-releasing strain of Bacillus edaphicus, enhanced plant growth and potassium uptake were reported under nutrient deficiency and heavy metal contamination in cotton and rapeseed [69]. Similarly, in this study, radish and pepper plants treated with the SB-3, SB-4, and St-3 cultures showed higher growth rates and increased antioxidant activity. The higher germination indices of TPP and TPF, and the higher growth rate of TPF indicated that treatment with SB-3, SB-4, and St-3 cultures was effective in stimulating radish growth in the presence of plant pathogens (Pythium ultimum and Fusarium oxysporum f. sp. lactucae) (Figure 8). Research showed that biological control agents including $S$. sasae can produce hydrolytic enzymes, such as protease, glucanases, amylase, and chitinase, to destroy the components of the fungal cell wall, which is an important mechanism involved in the biocontrol of phytopathogenic fungi [70].

The total phenol content and TEAC activity in pepper plant leaves were significantly higher in $\operatorname{Tr} \_5$ than in the control (Tr_4) but we found no differences in all the treatments in the presence of fungal pathogens (Figure 9b,d), indicating that amendment with SB-3, SB-4, and St-3 cultures can facilitate the production of antioxidants in the absence of the pathogens. Moreover, we found no differences in DPPH scavenging or total flavonoid content between $\operatorname{Tr}_{-} 4$ and $T r \_5$ in the presence and absence of the fungal pathogens, whereas DPPH scavenging significantly increased in the presence of the pathogen Fusarium oxysporum f. sp. lactucae (Figure 9a,c). The antioxidant mode of action was reported in many host-pathogen interactions. For example, many oxidative enzymes such as peroxidase, catalase, ascorbate oxidase, and polyphenol oxidase were detected as a result of infection with many pathogens [71]. In our study, the significant reduction in antioxidants (total phenolic content and TEAC) in Tr_4 PU, Tr_4 FO, Tr_5 PU, and Tr_5 FO (Figure $9 \mathrm{~b}, \mathrm{~d}$ ) might be due to inhibition by the fungal pathogens producing phenolic, benzoic, ferulic, coumaric, and protocatechoic acid [72]. In this study, amendment with SB-3, SB-4, and St-3 cultures did not seem to counteract the pathogen's functioning. Actinobacteria (i.e., Streptomyces sp.) combined with other plant-growth-promoting bacteria (i.e., Bacillus sp.) should be effective for the biocontrol of pathogens, plant growth promotion, and positive interaction with many plants [73].

\section{Conclusions}

The higher total flavonoid content in PT- 1 and the higher TEAC activity in PT- 1 and PT-2 proved the efficacy of the functional composts bioaugmented with functional microbes. The seedling growth of radish seeds treated with Streptomyces sasae St-3 as a biocontrol agent significantly increased even in the presence of the pathogen Fusarium oxysporum $\mathrm{f}$. sp. lactucae. The total phenol content and TEAC in pepper plant leaves were significantly higher in $\operatorname{Tr} \_5$ than in the control (Tr_4), whereas there were no differences in $\operatorname{Tr} \_4$ and $\operatorname{Tr}_{-} 5$ infested with the fungal pathogens, indicating that SB-3, SB-4, and St-3 cultures amended within the compost (Tr_5) may facilitate the production of the antioxidants in the absence of the pathogens. However, a significant reduction in the antioxidants (total phenolic content and TEAC) was observed in the pepper plants whose roots were infected with the pathogens, indicating that the pathogens could neutralize functionalities of the functional microbes. It was concluded that a good establishment of the functional microbes within the composts would contribute to the biocontrol of the pathogens in the soil environment. Further functional compost research is necessary on issues such as mechanisms of plant-growth promotion (production of plant growth regulators, enhanced iron availability by production of siderophores, nitrogen fixation, and phosphate solubilization), mechanisms of plantpathogen suppression by actinobacterial biocontrol agents (antibiotics, lytic enzymes, hyperparasitism, and competition), and the interaction between the two mechanisms in addition to quality enhancement of the composts. 


\section{Patents}

There is a patent resulting from the work reported in this manuscript: "Functional composts carrying spent coffee ground extracts and their manufacturing methods", Korea Patent No. 10-2021-0009108).

Author Contributions: Conceptualization, S.-C.K.; methodology, A.-E.S. and Y.-H.H.; software, A.-E.S.; investigation, A.-E.S. and S.-C.K.; writing-original draft preparation, A.-E.S.; writingreview and editing, S.-C.K.; visualization, S.-C.K.; supervision, S.-C.K.; project administration, Y.-H.H.; funding acquisition, S.-C.K. All authors have read and agreed to the published version of the manuscript.

Funding: This work was supported by the LINC+ Project 2020 grant sponsored by Ministry of Education and National Research Foundation, Korea (No. 2020-E-G055-010124).

Institutional Review Board Statement: Not applicable.

Informed Consent Statement: Not applicable.

Data Availability Statement: Not applicable.

Conflicts of Interest: The authors declare that they have no known competing financial interest or personal relationships that could have appeared to influence the work reported in this paper.

\section{References}

1. Evanylo, G.; Sherony, C.; Spargo, J.; Starner, D.; Brosius, M.; Haering, K. Soil and water environmental effects of fertilizer-, manure-, and compost-based fertility practices in an organic vegetable cropping system. Agric. Ecosyst. Environ. 2008, 127, 50-58. [CrossRef]

2. Lakhdar, A.; Scelza, R.; ben Achiba, W.; Scotti, R.; Rao, M.A.; Jedidi, N.; Abdelly, C.; Gianfreda, L. Effect of municipal solid waste compost and sewage sludge on enzymatic activities and wheat yield in a clayey-loamy soil. Soil Sci. 2011, 176, 15-21. [CrossRef]

3. Zhang, M.; He, L.-Y.; Liu, Y.-S.; Zhao, J.-L.; Zhang, J.-N.; Chen, J.; Zhang, Q.-Q.; Ying, G.-G. Variation of antibiotic resistome during commercial livestock manure composting. Environ. Int. 2020, 136, 105458. [CrossRef]

4. Nascimento, F.X.; Rossi, M.J.; Glick, B.R. Ethylene and 1-Aminocyclopropane-1-carboxylate (ACC) in Plant-Bacterial Interactions. Front. Plant Sci. 2018, 9, 114. [CrossRef]

5. Silva, C.F.; Azevedo, R.S.; Braga, C.; Da Silva, R.; Dias, E.S.; Schwan, R.F. Microbial diversity in a bagasse-based compost prepared for the production of Agaricus brasiliensis. Braz. J. Microbiol. 2009, 40, 590-600. [CrossRef]

6. Tucker, C.M. Coffee Culture, 2nd ed.; Anthropology of Stuff Series; Routledge: New York, NY, USA, 2018.

7. Getachew, A.T.; Chun, B.S. Influence of pretreatment and modifiers on subcritical water liquefaction of spent coffee grounds: A green waste valorization approach. J. Clean. Prod. 2017, 142, 3719-3727. [CrossRef]

8. Cruz, R.; Mendes, E.; Torrinha, Á.; Morais, S.; Pereira, J.A.; Baptista, P.; Casal, S. Revalorization of spent coffee residues by a direct agronomic approach. Food Res. Int. 2015, 73, 190-196. [CrossRef]

9. Cruz, R.; Gomes, T.; Ferreira, A.; Mendes, E.; Baptista, P.; Cunha, S.; Pereira, J.A.; Ramalhosa, E.; Casal, S. Antioxidant activity and bioactive compounds of lettuce improved by espresso coffee residues. Food Chem. 2014, 145, 95-101. [CrossRef] [PubMed]

10. Liu, K.; Price, G.W. Evaluation of three composting systems for the management of spent coffee grounds. Bioresour. Technol. 2011, 102, 7966-7974. [CrossRef] [PubMed]

11. Ribeiro, J.P.; Vicente, E.; Gomes, A.P.D.; Nunes, M.I.; Alves, C.; Tarelho, L.A.C. Effect of industrial and domestic ash from biomass combustion, and spent coffee grounds, on soil fertility and plant growth: Experiments at field conditions. Environ. Sci. Pollut. Res. 2017, 24, 15270-15277. [CrossRef]

12. Hardgrove, S.J.; Livesley, S.J. Applying spent coffee grounds directly to urban agriculture soils greatly reduces plant growth. Urban For. Urban Green. 2016, 18, 1-8. [CrossRef]

13. Gomes, T.; Pereira, J.; Ramalhosa, E.; Casal, S.; Baptista, P. Effect of Fresh and Composted Spent Coffee Grounds on Lettuce Growth, Photosynthetic Pigments and Mineral Composition. VII Congreso Ibérico de Agroingeniería y Ciencias Horticolas; SECH e SEAgIng. Available online: http:/ / hdl.handle.net/10198/8719 (accessed on 21 June 2021).

14. Ros, M.; Pascual, J.; Garcia, C.; Hernandez, T.; Insam, H. Hydrolase activities, microbial biomass and bacterial community in a soil after long-term amendment with different composts. Soil Biol. Biochem. 2006, 38, 3443-3452. [CrossRef]

15. Mussatto, S.I.; Carneiro, L.M.; Silva, J.P.A.; Roberto, I.C.; Teixeira, J.A. A study on chemical constituents and sugars extraction from spent coffee grounds. Carbohydr. Polym. 2011, 83, 368-374. [CrossRef]

16. Kondamudi, N.; Mohapatra, S.K.; Misra, M. Spent coffee grounds as a versatile source of green energy. J. Agric. Food Chem. 2008, 56, 11757-11760. [CrossRef] [PubMed]

17. Cruz, R.; Morais, S.; Mendes, E.; Pereira, J.A.; Baptista, P.; Casal, S. Improvement of vegetables elemental quality by espresso coffee residues. Food Chem. 2014, 148, 294-299. [CrossRef] [PubMed] 
18. Zuorro, A.; Lavecchia, R. Spent coffee grounds as a valuable source of phenolic compounds and bioenergy. J. Clean. Prod. 2012, 34, 49-56. [CrossRef]

19. Budihardjo, M.A.; Sutrisno, E.; Fatimah, M. Leaves composting process and the influence of rumen content and bran addition. MATEC Web Conf. 2018, 159, 2033. [CrossRef]

20. Chang, J.I.; Chen, Y. Effects of bulking agents on food waste composting. Bioresour. Technol. 2010, 101, 5917-5924. [CrossRef] [PubMed]

21. Moongngarm, A.; Daomukda, N.; Khumpika, S. Chemical compositions, phytochemicals, and antioxidant capacity of rice bran, rice bran layer, and rice germ. APCBEE Procedia 2012, 2, 73-79. [CrossRef]

22. Khan, M.A.I.; Ueno, K.; Horimoto, S.; Komai, F.; Tanaka, K.; Ono, Y. Evaluation of the use of rice bran compost for eco-friendly weed control in organic farming systems. Am. J. Environ. Sci. 2007, 3, 235-240. [CrossRef]

23. Wang, S.; Zhao, X.; Xing, G.; Yang, L. Large-scale biochar production from crop residue: A new idea and the biogas-energy pyrolysis system. BioResources 2012, 8, 8-11. [CrossRef]

24. Sanchez-Monedero, M.; Cayuela, M.L.; Roig, A.; Jindo, K.; Mondini, C.; Bolan, N. Role of biochar as an additive in organic waste composting. Bioresour. Technol. 2018, 247, 1155-1164. [CrossRef] [PubMed]

25. Malinowski, M.; Wolny-Koładka, K.; Vaverková, M. Effect of biochar addition on the OFMSW composting process under real conditions. Waste Manag. 2019, 84, 364-372. [CrossRef] [PubMed]

26. Mierzwa-Hersztek, M.; Wolny-Koładka, K.; Gondek, K.; Gałązka, A.; Gawryjołek, K. Effect of coapplication of biochar and nutrients on microbiocenotic composition, dehydrogenase activity index and chemical properties of sandy soil. Waste Biomass Valorization 2020, 11, 3911-3923. [CrossRef]

27. Deportes, I.; Guyod, B.; Zmirou, D.; Bouvier, M.C. Microbial disinfection capacity of municipal solid waste (MSW) composting. J. Appl. Microbiol. 1998, 85, 238-246. [CrossRef]

28. Fatunla, K.; Inam, E.; Essien, J.; Dan, E.; Odon, A.; Kang, S.; Semple, K.T. Influence of composting and thermal processing on the survival of microbial pathogens and nutritional status of Nigeria sewage sludge. Int. J. Recycl. Org. Waste Agric. 2017, 6, 301-310. [CrossRef]

29. Li, K.; Cao, R.; Mo, S.; Yao, R.; Ren, Z.; Wu, J. Swine manure composting with compound microbial inoculants: Removal of antibiotic resistance genes and their associations with microbial community. Front. Microbiol. 2020, 11, 2686. [CrossRef]

30. Danish, S.; Zafar-Ul-Hye, M.; Mohsin, F.; Hussain, M. ACC-deaminase producing plant growth promoting rhizobacteria and biochar mitigate adverse effects of drought stress on maize growth. PLoS ONE 2020, 15, e0230615. [CrossRef]

31. Danish, S.; Zafar-Ul-Hye, M. Combined role of ACC deaminase producing bacteria and biochar on cereals productivity under drought. Phyton 2020, 89, 217-227. [CrossRef]

32. Emmanuel, S.A.; Yoo, J.; Kim, E.-J.; Chang, J.-S.; Park, Y.-I.; Koh, S.-C. Development of functional composts using spent coffee grounds, poultry manure and biochar through microbial bioaugmentation. J. Environ. Sci. Health Part B 2017, 52, 802-811. [CrossRef]

33. Kim, I.-S.; Ekpeghere, K.I.; Ha, S.-Y.; Kim, B.-S.; Song, B.; Kim, J.-T.; Kim, H.-G.; Koh, S.-C. Full-scale biological treatment of tannery wastewater using the novel microbial consortium BM-S-1. J. Environ. Sci. Health Part A 2014, 49, 355-364. [CrossRef] [PubMed]

34. Chang, T.-C.; Jang, H.-D.; Lin, W.-D.; Duan, P.-F. Antioxidant and antimicrobial activities of commercial rice wine extracts of Taiwanese Allium fistulosum. Food Chem. 2016, 190, 724-729. [CrossRef] [PubMed]

35. Park, Y.-S.; Jung, S.-T.; Kang, S.-G.; Heo, B.G.; Arancibia-Avila, P.; Toledo-Montiel, F.; Drzewiecki, J.; Namiesnik, J.; Gorinstein, S. Antioxidants and proteins in ethylene-treated kiwifruits. Food Chem. 2008, 107, 640-648. [CrossRef]

36. Thaipong, K.; Boonprakob, U.; Crosby, K.; Cisneros-Zevallos, L.; Byrne, D.H. Comparison of ABTS, DPPH, FRAP, and ORAC assays for estimating antioxidant activity from guava fruit extracts. J. Food Compos. Anal. 2006, 19, 669-675. [CrossRef]

37. Jothy, S.L.; Zakaria, Z.; Chen, Y.; Lau, Y.L.; Latha, L.Y.; Sasidharan, S. Acute oral toxicity of methanolic seed extract of cassia fistula in mice. Molecules 2011, 16, 5268-5282. [CrossRef]

38. Gu, W.; Zhang, F.; Xu, P.; Tang, S.; Xie, K.; Huang, X.; Huang, Q. Effects of sulphur and Thiobacillus thioparus on cow manure aerobic composting. Bioresour. Technol. 2011, 102, 6529-6535. [CrossRef]

39. Stefan, V.; Van Herpen, E.; Tudoran, A.A.; Lähteenmäki, L. Avoiding food waste by Romanian consumers: The importance of planning and shopping routines. Food Qual. Prefer. 2013, 28, 375-381. [CrossRef]

40. Chitra, S.; Bargavi, P.; Balasubramaniam, M.; Chandran, R.R.; Balakumar, S. Impact of copper on in-vitro biomineralization, drug release efficacy and antimicrobial properties of bioactive glasses. Mater. Sci. Eng. C 2020, 109, 110598. [CrossRef]

41. Bidondo, L.F.; Pergola, M.; Silvani, V.; Colombo, R.; Bompadre, J.; Godeas, A. Continuous and long-term monoxenic culture of the arbuscular mycorrhizal fungus Gigaspora decipiens in root organ culture. Fungal Biol. 2012, 116, 729-735. [CrossRef]

42. Kang, S.-M.; Radhakrishnan, R.; Lee, I.-J. Bacillus amyloliquefaciens subsp. Plantarum GR53, a potent biocontrol agent resists Rhizoctonia disease on Chinese cabbage through hormonal and antioxidants regulation. World J. Microbiol. Biotechnol. 2015, 31, 1517-1527. [CrossRef]

43. Kuan, K.B.; Othman, R.; Rahim, K.A.; Shamsuddin, Z.H. Plant growth-promoting rhizobacteria inoculation to enhance vegetative growth, nitrogen fixation and nitrogen remobilisation of maize under greenhouse conditions. PLoS ONE 2016, 11, e0152478. [CrossRef] 
44. Theodorou, M.E.; Plaxton, W. Metabolic adaptations of plant respiration to nutritional phosphate deprivation. Plant Physiol. 1993, 101, 339-344. [CrossRef] [PubMed]

45. Kang, S.-M.; Radhakrishnan, R.; Khan, A.L.; Kim, M.-J.; Park, J.-M.; Kim, B.-R.; Shin, D.-H.; Lee, I.-J. Gibberellin secreting rhizobacterium, Pseudomonas putida H-2-3 modulates the hormonal and stress physiology of soybean to improve the plant growth under saline and drought conditions. Plant Physiol. Biochem. 2014, 84, 115-124. [CrossRef]

46. Zeng, Q.; Xie, J.; Li, Y.; Gao, T.; Xu, C.; Wang, Q. Comparative genomic and functional analyses of four sequenced Bacillus cereus genomes reveal conservation of genes relevant to plant-growth-promoting traits. Sci. Rep. 2018, 8, 17009. [CrossRef] [PubMed]

47. Pérez, G.C.; González, C.G.Z. Practices and conceptions of feedback in initial teacher training. Educ. Pesqui. 2019, 45, e192953. [CrossRef]

48. Rojas-Solis, D.; Vences-Guzmán, M.Á.; Sohlenkamp, C.; Santoyo, G. Antifungal and plant growth-promoting bacillus under saline stress modify their membrane composition. J. Soil Sci. Plant Nutr. 2020, 20, 1549-1559. [CrossRef]

49. Lyu, A.; Liu, H.; Che, H.; Yang, L.; Zhang, J.; Wu, M.; Chen, W.; Li, G. Reveromycins A and B from Streptomyces sp. 3-10: Antifungal activity against plant pathogenic fungi in vitro and in a strawberry food model system. Front. Microbiol. 2017, 8, 550 [CrossRef]

50. Getha, K.; Vikineswary, S. Antagonistic effects of Streptomyces violaceusniger strain G10 on Fusarium oxysporum f. sp. cubense race 4: Indirect evidence for the role of antibiosis in the antagonistic process. J. Ind. Microbiol. Biotechnol. 2002, 28, 303-310. [CrossRef] [PubMed]

51. Al-Askar, A.A.; Baka, Z.A.; Rashad, Y.M.; Ghoneem, K.M.; Abdulkhair, W.M.; Hafez, E.E.; Shabana, Y.M. Evaluation of Streptomyces griseorubens E44G for the biocontrol of Fusarium oxysporum f. sp. lycopersici: Ultrastructural and cytochemical investigations. Ann. Microbiol. 2015, 65, 1815-1824. [CrossRef]

52. Sudiana, I.M.; Putri, A.; Napitupulu, T.P.; Purnaningsih, I.; Kanti, A. Growth inhibition of Fusarium solani and F. oxysporum by Streptomyces sasae TG01, and its ability to solubilize insoluble phosphate. Biodiversitas J. Biol. Divers. 2020, 21. [CrossRef]

53. Hassanisaadi, M.; Bonjar, G.S.; Hosseinipour, A.; Abdolshahi, R.; Barka, E.A.; Saadoun, I. Biological control of Pythium aphanidermatum, the causal agent of tomato root rot by two Streptomyces root symbionts. Agronomy 2021, 11, 846. [CrossRef]

54. Medina, J.J.R.; Ramírez, K.; Rangel-Peraza, J.G.; Bustos-Terrones, Y.A. Increase of content and bioactivity of total phenolic compounds from spent coffee grounds through solid state fermentation by Bacillus clausii. J. Food Sci. Technol. 2018, 55, 915-923. [CrossRef]

55. González-Moreno, M.; Gracianteparaluceta, B.G.; Sádaba, S.M.; Urdin, J.Z.; Domínguez, E.R.; Ezcurdia, M.P.; Meneses, A.S. Feasibility of vermicomposting of spent coffee grounds and silverskin from coffee industries: A laboratory study. Agronomy 2020, 10, 1125. [CrossRef]

56. Priftis, A.; Mitsiou, D.; Halabalaki, M.; Ntasi, G.; Stagos, D.; Skaltsounis, L.A.; Kouretas, D. Roasting has a distinct effect on the antimutagenic activity of coffee varieties. Mutat. Res. Toxicol. Environ. Mutagen. 2018, 829-830, 33-42. [CrossRef]

57. Etesami, H.; Hosseini, H.M.; Alikhani, H.A. Bacterial biosynthesis of 1-aminocyclopropane-1-caboxylate (ACC) deaminase, a useful trait to elongation and endophytic colonization of the roots of rice under constant flooded conditions. Physiol. Mol. Biol. Plants 2014, 20, 425-434. [CrossRef]

58. Islam, M.; Kasim, S.; Alam, K.; Amin, A.; Hun, T.G.; Haque, M. Changes in chemical properties of banana pseudostem, mushroom media waste, and chicken manure through the co-composting process. Sustainability 2021, 13, 8458. [CrossRef]

59. Khan, M.A.I.; Ueno, K.; Horimoto, S.; Komai, F.; Tanaka, K.; Ono, Y. Evaluation of the upland weed control potentiality of green tea waste-Rice bran compost and its effect on spinach growth. Am. J. Agric. Biol. Sci. 2007, 2, 142-148. [CrossRef]

60. Mujtaba, G.; Hayat, R.; Hussain, Q.; Ahmed, M. Physio-chemical characterization of biochar, compost and co-composted biochar derived from green waste. Sustainability 2021, 13, 4628. [CrossRef]

61. Saini, A.; Aggarwal, N.K.; Sharma, A.; Yadav, A. Actinomycetes: A source of lignocellulolytic enzymes. Enzym. Res. 2015, 2015, 279381. [CrossRef] [PubMed]

62. Tortosa, G.; Castellano-Hinojosa, A.; Correa-Galeote, D.; Bedmar, E.J. Evolution of bacterial diversity during two-phase olive mill waste ("alperujo") composting by 16S rRNA gene pyrosequencing. Bioresour. Technol. 2017, 224, 101-111. [CrossRef]

63. Martins, L.F.; Antunes, L.P.; Pascon, R.C.; De Oliveira, J.C.F.; Digiampietri, L.A.; Barbosa, D.; Peixoto, B.M.; Vallim, M.; VianaNiero, C.; Ostroski, E.H.; et al. Metagenomic analysis of a tropical composting operation at the São Paulo zoo park reveals diversity of biomass degradation functions and organisms. PLoS ONE 2013, 8, e61928. [CrossRef]

64. Bosma, E.F.; Van De Weijer, A.H.P.; Van Der Vlist, L.; De Vos, W.M.; Van Der Oost, J.; Van Kranenburg, R. Establishment of markerless gene deletion tools in thermophilic Bacillus smithii and construction of multiple mutant strains. Microb. Cell Factories 2015, 14, 99. [CrossRef]

65. Yang, C.; Zhang, W.; Liu, R.; Li, Q.; Li, B.; Wang, S.; Song, C.; Qiao, C.; Mulchandani, A. Phylogenetic diversity and metabolic potential of activated sludge microbial communities in full-scale wastewater treatment plants. Environ. Sci. Technol. 2011, 45, 7408-7415. [CrossRef]

66. Pellegrini, M.; Spera, D.; Ercole, C.; Del Gallo, M. Allium cepa L. Inoculation with a consortium of plant growth-promoting bacteria: Effects on plants, soil, and the autochthonous microbial community. Microorganisms 2021, 9, 639. [CrossRef]

67. Tungmunnithum, D.; Thongboonyou, A.; Pholboon, A.; Yangsabai, A. Flavonoids and other phenolic compounds from medicinal plants for pharmaceutical and medical aspects: An overview. Medicines 2018, 5, 93. [CrossRef] 
68. Kumar, A.; Singh, S.; Gaurav, A.K.; Srivastava, S.; Verma, J.P. Plant growth-promoting bacteria: Biological tools for the mitigation of salinity stress in plants. Front. Microbiol. 2020, 11, 1216. [CrossRef]

69. Beckers, T.; Burkhardt, C.; Wieland, H.; Gimmnich, P.; Ciossek, T.; Maier, T.; Sanders, K. Distinct pharmacological properties of second generation HDAC inhibitors with the benzamide or hydroxamate head group. Int. J. Cancer 2007, 121, 1138-1148. [CrossRef] [PubMed]

70. Liu, H.; Guo, J.; Qu, J.; Lian, J.; Jefferson, W.; Yang, J.; Li, H. Catalyzing denitrification of Paracoccus versutus by immobilized 1,5-dichloroanthraquinone. Biodegradation 2011, 23, 399-405. [CrossRef]

71. Clark, L. DigitalCommons@University of Nebraska-Lincoln: A Review of Pathogens of Agricultural and Human Health Interest Found in Canada Geese. Available online: https:/ /digitalcommons.unl.edu/icwdm_usdanwrc/205/ (accessed on 21 June 2021).

72. Abdel-Monaim, M.F. Improvement of biocontrol of damping-off and root rot/wilt of faba bean by salicylic acid and hydrogen peroxide. Mycobiology 2013, 41, 47-55. [CrossRef] [PubMed]

73. Palaniyandi, S.A.; Yang, S.H.; Zhang, L.; Suh, J.-W. Effects of actinobacteria on plant disease suppression and growth promotion. Appl. Microbiol. Biotechnol. 2013, 97, 9621-9636. [CrossRef] 